\title{
Prediction of future hydrological regimes in poorly gauged high altitude basins: the case study of the upper Indus, Pakistan
}

\author{
D. Bocchiola ${ }^{1}$, G. Diolaiuti ${ }^{2}$, A. Soncini ${ }^{1}$, C. Mihalcea ${ }^{2}$, C. D'Agata ${ }^{2}$, C. Mayer ${ }^{3}$, A. Lambrecht ${ }^{4}$, R. Rosso ${ }^{1}$, and \\ C. Smiraglia ${ }^{2}$ \\ ${ }^{1}$ Dept. Hydrologic, Environmental, Roads and Surveying Engineering, Politecnico di Milano, L. Da Vinci, 32, \\ 20133, Milano, Italy \\ ${ }^{2}$ Dept. Earth Sciences, Università di Milano, Mangiagalli, 34, 20133, Milano, Italy \\ ${ }^{3}$ Commission for Glaciology, Bavarian Academy of Sciences, A. Goppel, 11, 80539 Munich, Germany \\ ${ }^{4}$ Institute of Meteorology and Geophysics, University of Innsbruck, Innrain 52, 6020 Innsbruck, Austria
}

Received: 13 April 2011 - Published in Hydrol. Earth Syst. Sci. Discuss.: 15 April 2011

Revised: 18 June 2011 - Accepted: 29 June 2011 - Published: 4 July 2011

\begin{abstract}
In the mountain regions of the Hindu Kush, Karakoram and Himalaya (HKH) the "third polar ice cap" of our planet, glaciers play the role of "water towers" by providing significant amount of melt water, especially in the dry season, essential for agriculture, drinking purposes, and hydropower production. Recently, most glaciers in the HKH have been retreating and losing mass, mainly due to significant regional warming, thus calling for assessment of future water resources availability for populations down slope. However, hydrology of these high altitude catchments is poorly studied and little understood. Most such catchments are poorly gauged, thus posing major issues in flow prediction therein, and representing in fact typical grounds of application of PUB concepts, where simple and portable hydrological modeling based upon scarce data amount is necessary for water budget estimation, and prediction under climate change conditions. In this preliminarily study, future (2060) hydrological flows in a particular watershed (Shigar river at Shigar, ca. $7000 \mathrm{~km}^{2}$ ), nested within the upper Indus basin and fed by seasonal melt from major glaciers, are investigated.
\end{abstract}

The study is carried out under the umbrella of the SHAREPaprika project, aiming at evaluating the impact of climate change upon hydrology of the upper Indus river. We set up a minimal hydrological model, tuned against a short series of observed ground climatic data from a number of stations in the area, in situ measured ice ablation data, and remotely sensed snow cover data. The future, locally adjusted, precip-

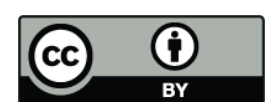

Correspondence to: D. Bocchiola (daniele.bocchiola@polimi.it) itation and temperature fields for the reference decade 2050 2059 from CCSM3 model, available within the IPCC's panel, are then fed to the hydrological model. We adopt four different glaciers' cover scenarios, to test sensitivity to decreased glacierized areas. The projected flow duration curves, and some selected flow descriptors are evaluated. The uncertainty of the results is then addressed, and use of the model for nearby catchments discussed. The proposed approach is valuable as a tool to investigate the hydrology of poorly gauged high altitude areas, and to project forward their hydrological behavior pending climate change.

\section{Introduction}

The mountain range of the Hindu Kush, Karakoram and Himalaya (HKH) contains a large amount of glacier ice, and it is the third pole of our planet (Smiraglia et al., 2007; Kehrwald et al., 2008), delivering water for agriculture, drinking purposes and power production. There are estimates indicating that more than $50 \%$ of the water flowing in the Indus river, Pakistan, which originates from the Karakoram, is due to snow and glacier melt (Immerzeel et al., 2010). The hydrological regimes of $\mathrm{HKH}$ rivers and potential impact of climate change therein have been hitherto assessed in a number of contribution in the available scientific literature (Aizen et al., 2002; Hannah et al., 2005; Kaser et al., 2010).

Economy of Himalayan regions is relying upon agriculture, and thus is highly dependent on water availability and irrigation systems (Akhtar et al., 2008). The Indo-Gangetic plain (IGP, including regions of Pakistan, India, Nepal, and Bangladesh) is challenged by increasing food production in

Published by Copernicus Publications on behalf of the European Geosciences Union. 
line with a tremendous growth of demand. Any perturbation in agriculture will considerably affect the food systems of the region and increase the vulnerability of the poor population (Aggarwal et al., 2004; Kahlown et al., 2007).

Nepal and northern India experience monsoonal floods during late summer (July-September), whereas in winter season (December-February) they display very low flows, terribly impacting agriculture.

The human settlements within HKH are tightly bound for their survival to agriculture, including wheat and more important sources of food integration (orchards, potato, tomato, Weiers, 1995). Agricultural irrigation in Pakistan rely heavily upon use of groundwater, and most of groundwater recharge is made up by irrigation water losses, with rainfall providing only some $10 \%$. Due to high evapotranspiration (ET) and severe salinity environment under which the irrigated agriculture is practiced, the available water is only marginally sufficient for year round cropping (Sarwar and Perry, 2002; Bhutta and Smedema, 2007).

The HKH stores a very relevant amount of water in its extensive glacier cover at higher altitudes (about $16300 \mathrm{~km}^{2}$ ), but the lower reaches are very dry. Especially in the Central and Northern Karakoram, the lower elevations receive only occasional rainfall during summer and winter (Winiger et al., 2005). The state of the glaciers also plays an important role in future planning: shrinking glaciers may initially provide more melt water, but later their amount may be reduced; on the other hand, growing glaciers store precipitation, reduce summer runoff, and can also generate local hazards. These differences could be caused by increases in precipitation since the 1960s (Archer and Fowler, 2004) and a simultaneous trend toward higher winter temperatures and lower summer temperatures (Fowler and Archer, 2005).

As such, climate change represent a main source of risk for floods and for the food security of the populations living within the area of HKH (Aggarwal et al., 2004). Despite the importance of this issue and the interest it has raised within the international scientific community, few studies were carried out assessing the impact of possible climate change in this area. Maybe less developed seems the assessment of water resources therein. Long term measurements of hydrological and climatologic data of the highest glacierized areas are seldom available (Chalise et al., 2003), thus making assessment of hydro-climatic trends difficult to say the least.

Recent studies indicate that glaciers of south-eastern Tibet have negative mass balances (Aizen and Aizen, 1994). Ageta and Kadota (1992) suggested that small glaciers in the Nepal Himalaya and Tibetan Plateau would disappear in a few decades if air temperature persistently exceeds a few degrees above that required for an equilibrium state of mass balance. Moreover, air pollution and in particular atmospheric soot seem to affect Himalayan glacier albedo, increasing ice and snow melting (Ming et al., 2007; Xu et al., 2009). Global warming should intensify the summer monsoon with consequent increased moisture fluxes, which could end the rise of local air temperature, and the mechanism of air temperature-precipitation and glacier interaction requires further scientific efforts (Aizen et al., 2002).

Akhtar et al. (2008) investigated hydrological conditions pending different climate change scenarios (using data from PRECIS initiative, Providing REgional Climates for Impacts Studies model, A2 storyline) for three glacierized watersheds in the HKH (Hunza, $13925 \mathrm{~km}^{2}$, glacierized $4688 \mathrm{~km}^{2}$; Gilgit, $12800 \mathrm{~km}^{2}$, glacierized $915 \mathrm{~km}^{2}$; Astore, $3750 \mathrm{~km}^{2}$, glacierized $612 \mathrm{~km}^{2}$ ). Their results indicate temperature and precipitation increase towards the end of 21 st century, with discharges increasing for $100 \%$ and $50 \%$ glacier cover scenarios, whereas noticeable decrease is conjectured for $0 \%$ scenario, i.e. for depletion of ice caps. Albeit the authors stress low quality of the observed data, they claim transfer of climate change signals into hydrological changes is consistent.

Immerzeel et al. (2009) used remotely sensed precipitation from TRMM (Tropical Rainfall Measuring Mission) satellite and snow covered area (henceforth SCA) from MODIS (Moderate Resolution Imaging Spectroradiometer), together with ground temperature data and a simple Snow Melt Runoff Model (SRM), to calibrate an hydrological model and then projected forward in time (PRECIS, 2071-2100) the hydrological response of the strongly snow fed Indus watershed (Pakistan, NW Himalaya, $200677 \mathrm{~km}^{2}$, including the Hunza and Gilgit basins). They found warming in all seasons, and greater at the highest altitudes, giving diminished snow fall, whereas total precipitation increases of $20 \%$ or so. They found snow melt peaks shifted up to one month earlier, increased glacial flow due to temperature, and significant increase of rainfall runoff.

While southern Himalaya is strongly influenced by the monsoon climate and by abundant seasonal precipitation therein, meteo-climatic conditions of Karakoram suggest a stricter dependence of water resources upon snow and ice ablation, and therefore the needs of its believable projection for the future (Mayer et al., 2010). In fact, most high altitude catchments in HKH are not gauged, or only poorly gauged, thus posing major issues in flow prediction therein.

Prediction in ungauged or poorly gauged basins is a tremendously important issue in modern hydrology, and a number of activities has been fostered within the scientific community in the last decade. Particularly, the International Association of Hydrological Sciences (IAHS) launched the PUB (Prediction in Ungauged Basins) initiative, covering the decade 2003-2012, and aimed to foster major advances in our capacity to make predictions in areas with poor coverage of hydrological data (Sivapalan et al., 2003; Seibert and Beven, 2009). High altitude glacierized catchments represent typical grounds of application of PUB concepts, where simple hydrological modeling based upon scarce data amount is necessary for water budget estimation, and prediction under climate change conditions (Chalise et al., 2003; Konz et al., 2007; Immerzeel et al., 2009; Bocchiola et al., 2010). Pillars 
of PUB initiative and methodology are the concepts of catchment classification (Burn, 1997; Gabriele and Arnell, 1991; Castellarin et al., 2001, 2008; Parajka et al., 2005; Merz and Blöschl, 2009) and model portability (Bárdossy, 2007; Buytaert et al., 2008; Castiglioni et al., 2010), basic tools to extrapolate results within measured areas to ungauged sites. However, use of such tools require accurate knowledge of physiographic, climatic and hydrologic attributes of some measured catchments within a certain region, and their proper treatment in order to complement analysis of unmeasured areas. Concerning HKH region, although some studies have been carried out concerning hydrological similarity (Hannah et al., 2005, for Nepal), and general hydrological regime (Archer, 2003 for three catchments in Karakoram), accurate studies about regional homogeneity and related spatial extent seem yet to come. Nor are the required data (weather, hydrology, topography, soil cover, etc.) easily available and widely spread, especially given the considerable altitude of the contributing catchments, where ice and snow plays a predominant role, and their dynamics is mostly unknown in practice. Upon such ground, development of a generally valid and accurate approach to regional hydrological modeling in this area seems beyond the present know how.

To initiate filling this gap we present here a simple approach to modeling of hydrological regime within a high altitude poorly gauged catchment, which illustrates one way to profit of scarce data coming from different sources, and may be of use in other unmeasured catchments of the area.

In this preliminarily study, we investigate hydrological flows in a particular watershed (Shigar river at Shigar, ca. $7000 \mathrm{~km}^{2}$ ), nested within the upper Indus basin, and fed by seasonal melt from major glaciers. The study is carried out under the umbrella of the SHARE-Paprika project (Stations at High Altitude for REsearch - CryosPheric responses to Anthropogenic PRessures in the HIndu KushHimalayAregions: impacts on water resources and availability), funded by the EVK2CNR (EVerest-K2-Consiglio Nazionale delle Ricerche) committee of Italy, aiming at evaluating the impact of climate change upon hydrology of the upper Indus river. We set up a minimal hydrological model, tuned against a short series of observed ground climatic data from a number of stations, in situ measured ablation, and remotely sensed snow covered areas. We then feed our model with locally adjusted future precipitation and temperature fields from one particular General Circulation Model (henceforth, GCM), namely the Community Climate System Model, version 3 (henceforth, CCSM3), available within the International Panel of Climate Change (IPCC) data base, using storyline A2, for the reference period 2050-2059. We adopt four different glaciers' cover scenarios, to test runoff sensitivity to decreasing size of glacierized areas. The projected flow duration curves, and some selected flow descriptors are evaluated. We then comment the modified snow cover, ice ablation regime and implications for water re- sources, displaying sensitivity to the chosen scenario. The uncertainty of the results is addressed, and some indications are given about how the simplified approach here proposed could be used to gather knowledge about ungauged catchments in this area.

\section{Case study area}

The study are is in the northern of Pakistan (Fig. 1), in the $\mathrm{HKH}$ region, ranging ca. from $74.5^{\circ} \mathrm{E}$ to $76.5^{\circ} \mathrm{E}$ in Longitude, and from $35.2^{\circ} \mathrm{N}$ to $37^{\circ} \mathrm{N}$ in Latitude. This preliminary study has been conducted in a particular watershed (Shigar river closed to Shigar bridge, ca. $7000 \mathrm{~km}^{2}$ ), nested within the upper Indus basin, and fed by seasonal melt from major glaciers. We tackled assessment of hydrology within this particular contributor to the Indus river because its whole catchment is laid within Pakistan, whereas a considerable part of the Indus catchment drains the mountain chains of China and India before flowing therein. This makes data retrieval easier, while fitting the purpose of the SHARE-Paprika project, specifically interested into the effect of climate change within the Karakoram range of Pakistan.

The highest altitude here is reached by $\mathrm{K} 2$ mountain (8611 meters above sea level, henceforth $\mathrm{ma.s.1}$.) and the lower is at Shigar bridge at $2204 \mathrm{~m}$ a.s.1., the average altitude is $4613 \mathrm{~m}$ a.s.l. and around the $35 \%$ of the area is above $5000 \mathrm{~m}$ a.s.1. According to the Köppen-Geiger climate classification (Peel et al., 2007) this area falls in a cold desert region, or BWK region, that displays dry climate with little precipitation and a wide daily temperature range. The HKH area displays considerable vertical gradients. The Nanga Parbat massif forms a barrier to the Northward movement of monsoon storms, which intrudes little in Karakoram. In the $\mathrm{HKH}$ range there is extensive coverage of glaciers. About $13000 \mathrm{~km}^{2}$ of glaciers are laid within Pakistan, and in the Shigar basin the main one is the Baltoro, with more than $700 \mathrm{~km}^{2}$ in area. Thus, the hydrological regime is little influenced by monsoon and a major contribution results from snowmelt and glacier melt. Precipitation is concentrated in two main periods, Winter (JFM) and summer (JAS), i.e. Monsoon and Westerlies, the latter providing the dominant nourishment for the glacier systems of the HKH. Some studies indicate that these mountains gain a total annual rainfall between $200 \mathrm{~mm}$ and $500 \mathrm{~mm}$, amounts that are generally derived from valley-based stations and less representative for the highest zones (Archer, 2003). High altitude snowfall seems to be neglected and is still rather unknown. Some estimates from accumulation pits above $4000 \mathrm{~m}$ a.s.l. range from $1000 \mathrm{~mm}$ to more than $3000 \mathrm{~mm}$, depending on the site (Winiger et al., 2005). However, there is considerable uncertainty about the behavior of precipitation at high altitudes. 


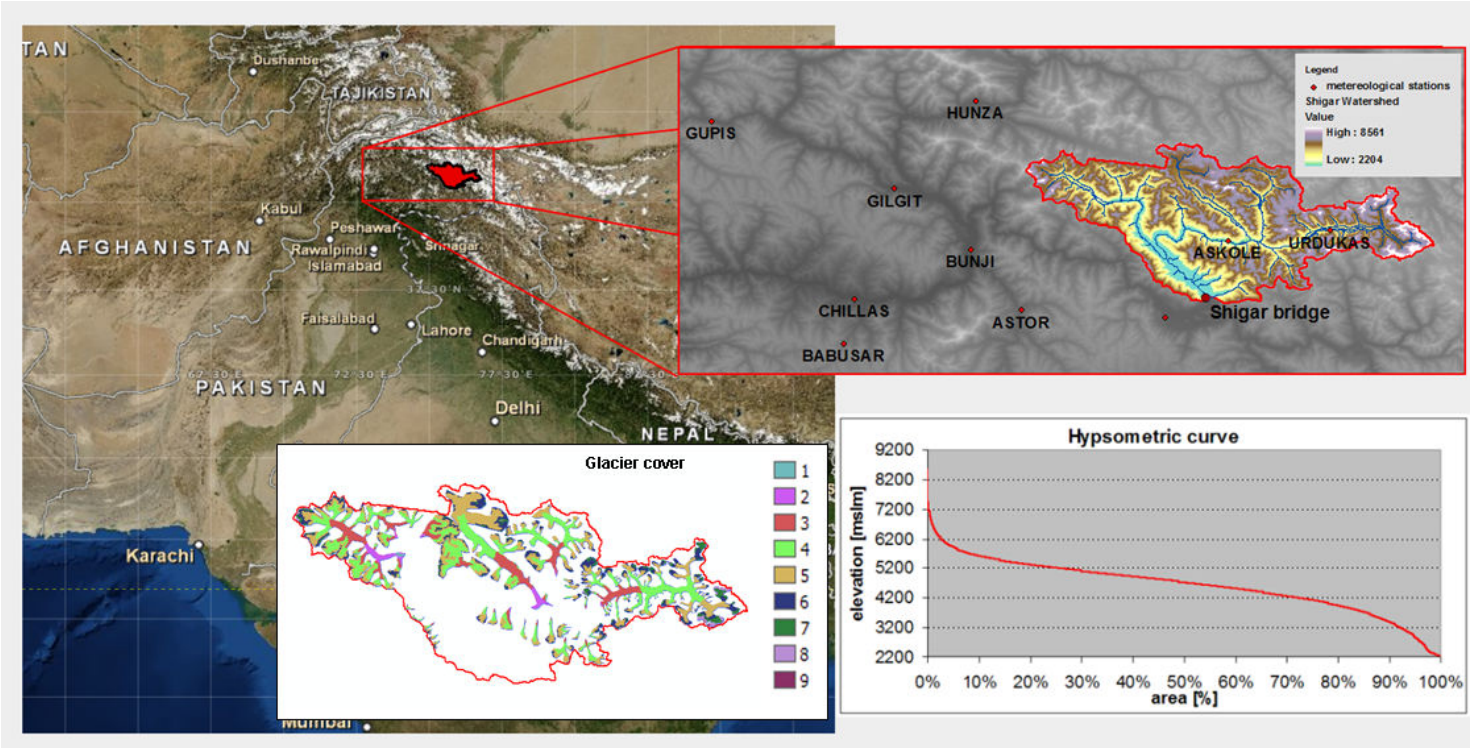

Fig. 1. The study area: Shigar river basin in the HKH region. Red dots are the weather stations. Glaciers' cover reported in the 10 chosen altitude belts (no glacier cover in belt 10).

\section{Database}

\subsection{Observed data}

In the Shigar river catchment we have available data from two meteorological stations, property of the EVK2CNR committee: Askole (3015 ma.s.1.), and Urdukas ( $3926 \mathrm{~m}$ a.s.l.). For these stations there are available daily values of rainfall and mean air temperature for the period 2005-2009, but with significant missing data periods, especially for the precipitation. These gaps are concentrated particularly in Winter, likely as precipitation falls under snow form, not measured at these stations. Out of the Shigar basin weather data are available, namely the monthly values of precipitation and temperature during 1980-2009, for 8 stations belonging to Pakistan Meteorological Department, PMD, all positioned below $2500 \mathrm{~m}$ a.s.l. Monthly mean discharge averaged over the period from 1985 until 1997 are available. During this period there was a hydrometric station property of the WAter Power Development Agency of Pakistan WAPDA at the Shigar bridge (2204 m a.s.l.), that is our control section (Archer, 2003). Weather data coverage is summarized in Table 1.

\subsection{SCA data}

We here used SCA as derived from MODIS images. Nowadays, SCA estimation from satellite data is widely adopted for water storage assessment in mountain areas, distributed modeling of snow cover and melting and hydrological and glaciological implications therein (Swamy and Brivio, 1996; Simpson et al., 1998; Cagnati et al., 2004; Hauser et al.,
2005; Parajka and Blöschl, 2008; Georgievsky, 2009; Immerzeel et al., 2009). Unsupervised classification of SCA may be carried out based upon visible bands (Red, Green, Blue, RGB) and box type classification (Hall et al., 2003a, b; Hall et al., 2010, for estimation of SCA from MODIS ${ }^{\circledR}$ images), using digital number, $\mathrm{DN}>200$.

Also sub-pixel classification is used, e.g. by spectral unmixing. (Foppa et al., 2004), which still requires subjective choice of end-members (and more spectral bands for more end-members), while the main output is a percentage of in cell snow coverage, with no indication of spatial distribution of cells with snow. Here we used 40 images of SCA from MODIS during 2006-2008, taken from the product MODIS/Terra Maximum-Snow Cover 8-Day, L3 Global, at a $500 \mathrm{~m}$ resolution (MOD10A2, Hall et al., 2002). This contains Maximum SCA (presence/absence of snow cover) over an 8-day composing period. As no snow cover data were available within the catchment, as reported, we could not attempt either spatial estimation of snow cover (Bocchiola, 2010; Bocchiola and Groppelli, 2010), or investigation of snowfall properties in the area (Bocchiola and Rosso, 2007).

\subsection{GCM data}

We use here the model NCAR-CCSM3, recently released by the National Centre for Atmospheric Research (NCAR), in Boulder, Colorado. This model has been included within the 3rd IPCC report (2007) and appears to be more accurate compared with some others GCMs, e.g. on the Italian Alps (Soncini and Bocchiola, in press), and its resolution is comparatively finer with respect to other models. The Shigar basin falls into three cells of the CCSM3 model (Fig. 2, 
Table 1. Weather stations and measured variables during 2005-2008.

\begin{tabular}{|c|c|c|c|c|c|}
\hline Station & $\begin{array}{l}\text { Altitude } \\
\text { [m a.s.1.] }\end{array}$ & $\begin{array}{l}\text { Long } \\
{\left[{ }^{\circ} \mathrm{E}\right]}\end{array}$ & $\begin{array}{r}\text { Lat } \\
{\left[{ }^{\circ} \mathrm{N}\right]}\end{array}$ & Variable & $\begin{array}{l}\text { Resolution } \\
{[-]}\end{array}$ \\
\hline URDUKAS & 3926 & 76.28611 & 35.72805 & Temp, Precip & Daily \\
\hline ASKOLE & 3015 & 75.81527 & 35.68056 & Temp, Precip & Daily \\
\hline ASTOR & 2168 & 74.86709 & 35.36341 & Temp, Precip & Monthly \\
\hline BABUSAR & 2854 & 74.05287 & 35.20946 & Temp, Precip & Monthly \\
\hline BUNJI & 1470 & 74.63503 & 35.6423 & Temp, Precip & Monthly \\
\hline CHILAS & 1255 & 74.09936 & 35.41533 & Temp, Precip & Monthly \\
\hline GILGIT & 1461 & 74.28351 & 35.92029 & Temp, Precip & Monthly \\
\hline GUPIS & 2156 & 73.44538 & 36.23088 & Temp, Precip & Monthly \\
\hline HUNZA & 2374 & 74.65969 & 36.32441 & Temp, Precip & Monthly \\
\hline SKARDU & 2230 & 75.52631 & 35.32965 & Temp, Precip & Monthly \\
\hline
\end{tabular}

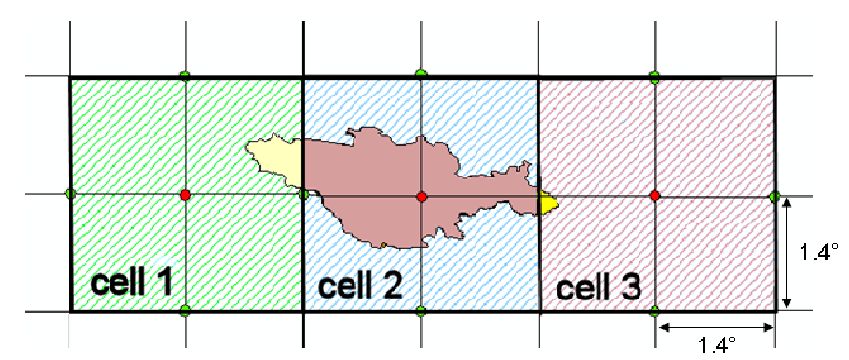

Fig. 2. Grids of the chosen GCM model upon the Shigar watershed.

Table 2), albeit mostly contained in the centre one. Here, we evaluate temperature and precipitation within the basin by area weighting. Typically, GCMs provide a bad representation of small scale effects upon precipitation, e.g. topographic control. Therefore, a downscaling is necessary (Groppelli et al., 2011a). Still, GCMs carry considerable information concerning large scale forcing to local climate, so their use is appropriate for projections of climate change impact. The simulations of the GCMs use as input different hypothesis of the future world situation (storylines). The Special Report on Emission Scenarios - SRES by the Intergovernmental Panel on Climate Change (Nakicenovic and Swart, 2000) described four possible future storylines (A1, A2, B1, B2), each one refers to the effect of different potential causes of greenhouse gases (hereafter GHG) emissions and to their possible future dynamics. We used the data generated via the IPCC SRES A2 Scenario, so described by Beniston (2004): "A2 scenarios assume little change in economic behavior. In addition, rising population levels and relatively little international collaboration on resource and environmental protection exacerbate the problem of emissions; the A2 are sometimes referred to as "Business-as-usual", a phrase that was coined for one of the previous sets of IPCC scenarios". A2 storyline is most often adopted for climate projections, so we use it also here.

\section{Methods}

\subsection{Weather data}

To provide input data to our hydrological model for the purpose of testing its performance we proceed as follows. We use yearly total precipitation from the 8 PMD stations during 1980-2009 (overlapping the period of functioning of the WAPDA hydrometric station on the Shigar river, 1985-1997) to evaluate the presence and magnitude of altitude lapse rate of temperature and precipitation, and monthly lapse rates were used. Given to the considerable amount of missing days (especially during winter for snowfall), the precipitation data from Askole (3015 m a.s.1.) and Urdukas (3926 m a.s.1.) could not be used here. The existence and magnitude of a precipitation drift against altitude in this area is an important task of research (Winiger et al., 2005; Bookhagen and Burbank, 2006; 2010). Winiger et al. (2005) demonstrated that total precipitation within Karakoram region may be reasonably interpreted to vary according to a power low up to $5000 \mathrm{~m}$ a.s.l. (Fig. 8 therein). Our precipitation data here show an increase from $1200 \mathrm{~m}$ a.s.l. to $3000 \mathrm{~m}$ a.s.l. or so. We interpret such increase using a power law according to Winiger et al. (2005), which we estimate from the PMD data

$P_{y}=9 \times 10^{-6} z^{2.22}$,

with $P_{y}$ yearly amount of precipitation $[\mathrm{mm}]$ and $z$ is altitude [ma.s.l.]. We preliminarily evaluated the presence of an altitude lapse rate of precipitation by analyzing maps of average yearly precipitation as derived from TRMM satellite data during 1998-2009 (kindly provided by B. Bookhagen of UCSB, Bookhagen and Burbank, 2006, 2010) for the Shigar basin area, but these maps indicated in practice no significant change (either increase or decrease) of precipitation against altitude. As a rough comparison, average precipitation in the area could be estimated in ca. $350 \mathrm{~mm} \mathrm{year}^{-1}$ by TRMM, whereas use of Eq. (1) provided an expected value of ca. $550 \mathrm{~mm}_{\text {year }}{ }^{-1}$, i.e. with a difference of $35 \%$ or 
Table 2. Description of GCM model.

\begin{tabular}{|c|c|c|c|c|c|}
\hline Model & Research Centre & Nation & $\begin{array}{c}\text { Grid size } \\
{\left[{ }^{\circ}\right]}\end{array}$ & $\begin{array}{c}\mathrm{n}^{\circ} \text { cells } \\
{[-]}\end{array}$ & $\begin{array}{c}\mathrm{n}^{\circ} \text { layers } \\
{[-]}\end{array}$ \\
\hline CCSM3 & National Center for Atmospheric Research & USA & $1.4^{\circ} \times 1.4^{\circ}$ & $256 \times 128$ & 26 \\
\hline
\end{tabular}

so. However, given the tremendous uncertainty in both techniques, such spread seems not unexpected. Given the noticeable noise in precipitation estimation using remote sensing data, here we prefer to rely upon ground observations, albeit few. Extension of power law above $5000 \mathrm{~m}$ a.s.l. may indeed result into overestimation of precipitation at high altitudes, but given the lack of direct observations, there is little way to assess this approach.

Using the daily precipitation data during 2005-2008 at the Askole station of EVK2CNR, most complete when compared against Urdukas, we then set up a disaggregation approach, which we use to disaggregate monthly precipitation from Astore station (most complete data base among the PMD stations). We use a random cascade approach (Groppelli et al., 2010, 2011a), slightly modified to deal with monthly precipitation, namely

$$
\begin{aligned}
& R_{\mathrm{d}}=R_{\mathrm{m}} Y_{\mathrm{d}}=R_{\mathrm{m}} B_{\mathrm{d}} W_{\mathrm{d}} \\
& P\left(B_{\mathrm{d}}=0\right)=1-p_{\mathrm{d}} \\
& P\left(B_{\mathrm{d}}=p_{\mathrm{d}}^{-1}\right)=p_{\mathrm{d}} \\
& E\left[B_{\mathrm{d}}\right]=p_{\mathrm{d}}^{-1} p_{\mathrm{d}}+0\left(1-p_{\mathrm{d}}\right)=1, \\
& W_{\mathrm{d}}=e^{\left(w_{\mathrm{d}}-\sigma_{\mathrm{wd}}^{2} / 2\right)} \\
& E\left[W_{\mathrm{d}}\right]=1 ; w_{\mathrm{d}}=N\left(0, \sigma_{\mathrm{d}}^{2}\right)
\end{aligned}
$$

where $R_{\mathrm{m}}$ is monthly rainfall, $R_{\mathrm{d}}$ is daily rainfall, and $Y_{\mathrm{d}}$ a daily cascade weight. $B_{\mathrm{d}}, p_{\mathrm{d}}$, and $\sigma_{\mathrm{wd}}^{2}$ are model parameters, to be estimated from data, used to preserve intermittence, or correct sequence of dry and wet spells. The term $B_{\mathrm{d}}$ is a $\beta$ model generator (Over and Gupta, 1994). It gives the probability that the rain rate $R_{\mathrm{d}}$ for a given day is non zero, conditioned upon $R_{\mathrm{m}}$ being positive, and it is modeled here by a binomial distribution. The term $W_{\mathrm{d}}$ is a "strictly positive" generator. It is used to add a proper amount of variability to precipitation during spells labeled as wet. Model estimation (i.e. estimation of $p_{\mathrm{d}}$, and $\sigma_{\mathrm{wd}}^{2}$ ) is pursued monthly, based upon the 2005-2008 series at Askole. Then, in the hypothesis of similar statistic structure of precipitation between Askole and Astore we use the same approach to downscale monthly precipitation in Astore. So doing, we obtain a daily precipitation series at Astore, which we subsequently use for hydrological simulation during 1985-1997. Similarly, we use Askole daily temperature data, to disaggregate Astore monthly data, by random extraction of daily temperature according to a given (normal) distribution, estimated from data.

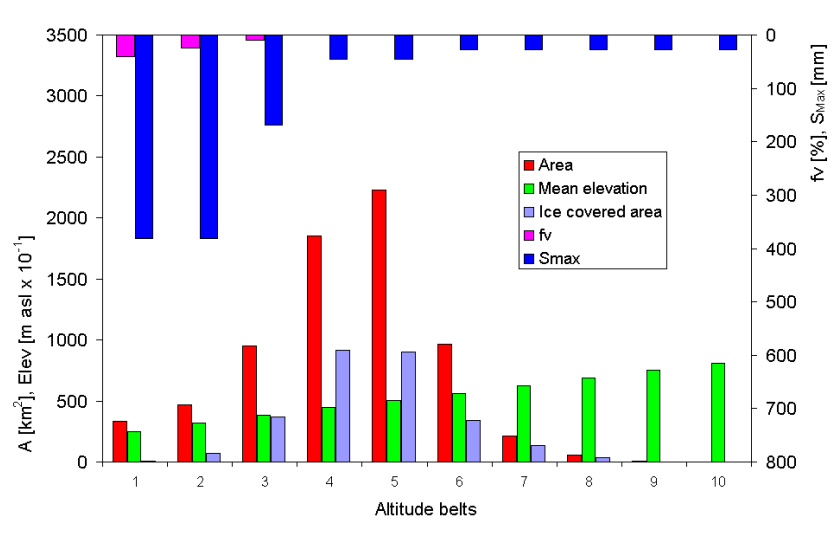

Fig. 3. Main features of the hydrological model altitude belts. $\mathrm{A}$ is altitude belt surface, Elev is mean belt elevation (scaled as Elev $\times 10^{-1}$ for readability), $f_{\mathrm{V}}$ is vegetated fraction, $S_{\mathrm{Max}}[\mathrm{mm}]$ is maximum soil retention.

\subsection{Ice melt}

Shigar watershed includes glaciers spread over a considerable area, several of which displaying debris cover. Mihalcea et al. (2006) and Mayer et al. (2006) evaluated ice melt factors for both ice covered and ice free glacier based upon field ablation data from the Baltoro glacier, and Mayer et al. (2010) evaluated melt factors for Bagrot valley, and Hinarche glacier. Mihalcea et al. (2008) provided evaluation of debris cover thickness again upon Baltoro. We classified ice covered area (Fig. 1) within the ten altitude belts as used in the hydrological model (Fig. 3) using visible images, and compared our estimates glaciers' inventory from ICIMOD (International Centre for Integrated MOuntain Development, Campbell, 2004) within the Shigar catchment. We obtained an ice covered area of ca. $2774 \mathrm{~km}^{2}$ vs. $2240 \mathrm{~km}^{2}$ as from ICIMOD. We used debris cover extent and distribution as drawn from Baltoro glaciers to evaluate melt factors in the glacier covered area of the Shigar catchment. As a rough average value on the area we found a melt factor for ice $D_{\mathrm{Di}}=5.70 \mathrm{~mm}^{\circ} \mathrm{C}^{-1} \mathrm{day}^{-1}$.

\subsection{Snow melt and SCA}

Snow melt was tackled using degree day approach and melt factor. Among others, Singh et al. (2000) provide a review of plausible values for snow melt factors, including 
Table 3. Shigar at Shigar bridge. Hydrological model parameters. In bold values calibrated against observed discharges.

\begin{tabular}{llll}
\hline Parameter & Description & Value & Method \\
\hline$k_{\mathrm{g}}, k_{\mathrm{S}}[\mathrm{d}]$ & Reservoir time constant, ground/overland & $\mathbf{2 0 , 5}$ & Basin morphology \\
$n_{\mathrm{g}}, n_{\mathrm{s}}$ & Reservoirs, ground/overland & $3 / 3$ & Literature \\
$K\left[\mathrm{mmd}^{-1}\right]$ & Saturated conductivity & $\mathbf{0 . 5}$ & Calibration \\
$k[-]$ & Groundwater flow exponent & $\mathbf{0 . 5}$ & Calibration \\
$f_{\mathrm{V}}[\%]$ & Vegetation cover, average value & 4.8 & Soil cover \\
$\theta_{\mathrm{W}}, \theta_{1}[-]$ & Water content, wilting /field capacity & $0.15,0.35$ & Literature \\
$S_{\mathrm{Max}}[\mathrm{mm}]$ & Maximum soil storage, average & 97 & Soil cover \\
\hline
\end{tabular}

for glaciers in western Himalaya. Melt factors range from $1 \mathrm{~mm}^{\circ} \mathrm{C}^{-1} \mathrm{day}^{-1}$ to $14 \mathrm{~mm}^{\circ} \mathrm{C}^{-1} \mathrm{day}^{-1}$ or so. Snow cover data (and subsequent ablation) were not available here, so we tackled estimation of melt factors indirectly. We used our hydrological model to simulate snow cover at different altitudes for different values of the melt factors, during years 2005-2008, when weather data from EVK2CNR stations were available, and also MODIS SCA data could be retrieved. We then compared the estimated snow cover depth, or Snow Water Equivalent (henceforth, SWE), including no snow, against SCA given by MODIS images for 2006-2008. Year 2005 was not considered, because no information about snowfall during the antecedent Fall was available to be used as a boundary condition. We then estimated a best value for the snow melt factor, as the one providing the best correspondence in term of SCA variation, snow depletion period, and snow melt flows.

\subsection{The hydrological model}

We use a semi-distributed altitude belts based model (Fig. 3), able to reproduce deposition of snow and ablation of both ice and snow, evapotranspiration, recharge of groundwater reservoir, discharge formation and routing to the control section (Groppelli et al., 2011b, c). We decided here to pursue daily modelling of the hydrological cycle of the area. Notice that modelling of snow and ice melt, considerably important here, requires at least use of daily meteo data, i.e. for degree day approach, widely diffused for the purpose (Singh et al., 2000; Bocchiola et al., 2010). Further, soil moisture, evapotranspiration, and flow production are non linear processes related to temperature and rainfall (SCS, 1986; Brutsaert, 2005; Chen et al., 2005), thus use of a different time scale (e.g. monthly) would not provide an appropriate description of the complexity of the hydrological cycle. Our model needs a few input data, i.e. a Digital Elevation Model (henceforth, DEM), daily values of precipitation and temperature, information about soil use, vertical gradient of temperature and precipitation and some parameters, reported in Table 3. The model is a simplified version of model DHM, Distributed Hydrological
Model (Wigmosta et al., 1994; Chen et al., 2005). In this model two mechanism of flow formation are considered, superficial and groundwater. The model is based on mass conservation equation and evaluates for each time step the variation of the soil water content in the ground layer. Soil water content $S$ in two consecutive time steps $(t, t+\Delta t)$, is

$S^{t+\Delta t}=S^{t}+R+M_{\mathrm{s}}+M_{i}-\mathrm{ET}_{\mathrm{eff}}-Q_{\mathrm{g}}$,

with $R$ the liquid rain, $M_{\mathrm{s}}$ snowmelt, $M_{i}$ glacial ablation, $\mathrm{ET}_{\text {eff }}$ the effective evapotranspiration, and $Q_{\mathrm{g}}$ groundwater discharge. Snowmelt $M_{\mathrm{s}}$ and glacial ablation $M_{i}$ are estimated according to a degree day method

$M_{\mathrm{s}}=D_{\mathrm{Ds}}\left(T-T_{t}\right), M_{i}=D_{\mathrm{Di}}\left(T-T_{t}\right)$,

with $T$ daily mean temperature, $D_{\mathrm{Ds}}$ and $D_{\mathrm{Di}}$ melt factors, evaluated as reported above, and $T_{t}$ threshold temperature, $T_{t}=0{ }^{\circ} \mathrm{C}$ (Bocchiola et al., 2010). Degree day plus melt factor is a simple and parsimonious method for assessment of ablation and floods in mountain catchments, and it is used here accordingly (Singh et al., 2000; Hock, 2003; Simaityte et al., 2008). Ice melt occurs upon glacier covered area within each belt (Fig. 3), after snow depletion is complete. The superficial flow $Q_{\text {s }}$ occurs only for saturated soil

$\begin{array}{ll}Q_{\mathrm{s}}=S^{t+\Delta t}-S_{\mathrm{Max}} & \text { if } S^{t+\Delta t}>S_{\mathrm{Max}} \\ Q_{\mathrm{s}}=0 & \text { if } S^{t+\Delta t} \leq S_{\mathrm{Max}}\end{array}$

with $S_{\text {Max }}$ greatest potential soil storage [mm]. Potential evapotranspiration is calculated using Hargreaves equation, only requiring temperature data and monthly mean temperature excursion

$\mathrm{ETP}=0.0023 S_{0} \sqrt{D T_{\mathrm{m}}}(T+17.8)$,

in $\mathrm{mmd}^{-1}$, where $S_{0}\left[\mathrm{mmd}^{-1}\right]$ is the evaporating power of solar radiation (depending upon Julian date and local coordinates), and $\mathrm{DT}_{\mathrm{m}}\left[{ }^{\circ} \mathrm{C}\right]$ is the thermometric monthly mean excursion. Once potential evapotranspiration is known, effective evapotranspiration $\mathrm{ET}_{\text {eff }}$ can be calculated. $\mathrm{ET}_{\text {eff }}$ is made of effective evaporation from the ground $E_{\mathrm{s}}$ and of effective transpiration from the vegetation $T_{\mathrm{s}}$, both functions of ETP via two coefficients $\alpha$ and $\beta$, depending on the state of 
soil moisture (water content, $\theta$, given by $S / S_{\mathrm{Max}}$ ) and from the fraction of vegetated soil $\left(f_{\mathrm{v}}\right)$ upon the surface of the basin (Brutsaert, 2005; Chen et al., 2005)

Es $=\alpha(\theta) \operatorname{ETP}\left(1-f_{\mathrm{v}}\right) T s=\beta(\theta) \operatorname{ETP} f_{\mathrm{v}}$,

with

$\alpha(\theta)=0.082 \theta+9.173 \theta^{2}-9.815 \theta^{3}$

$\beta(\theta)=\frac{\theta-\theta_{\mathrm{w}}}{\theta_{\mathrm{l}}-\theta_{\mathrm{w}}} \quad$ if $\theta>\theta_{\mathrm{w}}$

$\beta(\theta)=0$

if $\theta \leq \theta_{\mathrm{w}}$,

where $\theta_{\mathrm{w}}$ is wilting point water content, while $\theta_{1}$ is water content at field capacity. Actual evapotranspiration is then

$\mathrm{ET}_{\mathrm{eff}}=\mathrm{Es}+T s$.

Groundwater discharge is here simply expressed as a function of soil hydraulic conductivity and water content (Chen et al., 2005)

$Q_{\mathrm{g}}=K\left(\frac{S}{S_{\mathrm{Max}}}\right)^{k}$

with $K$ saturated permeability and $k$ power exponent. Equations (3-10) are solved using ten equally spaced elevation belts inside the basin. The flow discharges from the belts are routed to the outlet section through a semi-distributed flow routing algorithm. This algorithm is based upon the conceptual model of the instantaneous unit hydrograph, IUH (Rosso, 1984). For calculation of the in stream discharge we hypothesize two (parallel) systems (groundwater, overland) of linear reservoirs (in series) each one with a given number of reservoirs $\left(n_{\mathrm{g}}\right.$ and $\left.n_{\mathrm{s}}\right)$. Each of such reservoirs possesses a time constant (i.e. $k_{\mathrm{g}}, k_{\mathrm{s}}$ ). We assumed that for every belt the lag time grows proportionally to the altitude jump to the outlet section, until the greatest lag time (i.e. $T_{\text {lag,g }}=n_{\mathrm{g}} k_{\mathrm{g}}$ for the groundwater system and $T_{\mathrm{lag}, \mathrm{s}}=n_{\mathrm{s}} k_{\mathrm{s}}$ for the overland system). So doing, each belt possesses different lag times (and the farther belts the greater lag times).

The hydrological model uses a daily series of precipitation and temperature from one representative station, here Astore, and the estimated vertical gradients to project those variables at each altitude belt. Topography is here represented by a DTM model, with $30 \mathrm{~m}$ spatial resolution, derived from ASTER (Advanced Spaceborne Thermal Emission and Reflection Radiometer, 2006) mission, used to define altitude belts and local weather variables against altitude.

\subsection{Hydrological model calibration}

As reported above, we synthetically simulate daily series of temperature and precipitation for 1985-1997 by disaggregation of monthly values. We feed these data to our model, to obtain daily estimates of in channel discharge at Shigar bridge. We subsequently evaluate monthly mean discharges, which we then average during 1985-1997. So doing, we can compare mean monthly simulated discharges against their observed counterparts. As reported, only mean monthly discharges are available to us. Whenever daily, or monthly discharges for the area would be made available to us, we could compare those against model simulated discharges.

In Table 3 they are specified the parameters that were effectively used for the calibration, and those that were estimated on the basis of preliminary considerations and of the analysis of the available literature. Among the model parameters, the value of $S_{\mathrm{Max}}$ is of considerable interest, since it drives the production of overland flow. If one compares this parameter to the parameter S of the method of the Soil Conservation Service - Curve Number (SCS-CN, SCS, 1986), which possesses the analogous meaning of maximum soil storage, it is possible to estimate in the first instance the value of $S_{\text {Max }}$ based upon that method. Analysis of the land cover of the area (mostly shallow soils, bare rock and ice) from satellite images (visible), plus the geological maps (on a paper support) allowed us to define reasonable $\mathrm{CN}$ values for each belt, thus making it possible to evaluate $S_{\text {Max }}$.

The wilting point for the (scarce) vegetated areas $\theta_{\mathrm{w}}=0.15$ was chosen based upon available references (Chen et al., 2005; Wang et al., 2009). The field capacity was set to $\theta_{1}=0.35$, using an average value for mixed grounds, according to studies on a wide range of soils (Ceres et al., 2009).

Often the number of reservoirs in the overland flow phase depends on the morphology of the basin, expressed e.g. through morphometric indexes (Rosso, 1984). However, an analysis of the values observed within several studies indicates an average value of $n_{\mathrm{s}}=3$, which we use here. In analogy, the number of groundwater reservoirs may be linked to the topography, and we set $n_{\mathrm{g}}=3$. A greater variability is instead necessary for the appraisal of the time constants $k_{\mathrm{s}}$, $k_{\mathrm{g}}$, that define the lag time of the catchment, and are linked in some way to its size and to the characteristic flow velocity (Bocchiola et al., 2004; Bocchiola and Rosso, 2009).

We tuned the remaining parameters (see Table 3 ) with attention to two main goals: accuracy of the yearly average discharge and best fitting to the observed monthly mean series (least sum of percentage squared errors, $\mathrm{MSE} \%$ ).

We estimated the values of $k_{\mathrm{S}}$ and $k_{\mathrm{g}}$ by minimizing $\mathrm{MSE} \%$. These values do influence flow modeling at the daily scale, but at a monthly and yearly scale we saw little sensitivity.

The saturated permeability value $K=0.5 \mathrm{~mm} \mathrm{~d}^{-1}$ is consistent with the available literature for a range wide of observed soils, where values between $0.1 \mathrm{~mm} \mathrm{~d}^{-1}$ and $10 \mathrm{~mm} \mathrm{~d}^{-1}$ are found (Timlin et al., 1999; Wang et al., 2009). This parameter has substantial importance during periods of low flows. Here we found that the assumption of ground flow linearly dependent against water content $(k=1)$ was not accurate. Comparison against (averaged) discharges during low flows period (approx. October to May) for 1985-1997 indicated that a value of $k=0.5$ is suitable to better describe the hydrological cycle of the river. 


\subsection{GCMs downscaling}

To evaluate prospective hydrological cycle of the Shigar River, we downscale CCSM3 models' outputs of precipitation and temperature. Again, a random cascade approach (Groppelli et al., 2011a) is used to obtain ground precipitation at day $i$

$$
\begin{aligned}
& R_{i}=R_{C C S M}{ }_{, i} Y_{i}=R_{C C S M}{ }_{, i} B_{i} W_{i} \\
& P\left(B_{i}=0\right)=1-p_{i} \\
& P\left(B_{i}=p_{i}^{-1}\right)=p_{i} \\
& E\left[B_{i}\right]=p_{i}^{-1} p_{i}+0\left(1-p_{i}\right)=1 \\
& W_{i}=e^{\left(w_{i}-\sigma_{w i}^{2} / 2\right)} \\
& E\left[W_{i}\right]=1 ; w_{i}=N\left(0, \sigma_{i}^{2}\right)
\end{aligned}
$$

with $R_{C C S M}{ }_{, i}$ projected $C C S M 3$ precipitation at day $i$, and cascade model symbols having the same meaning as in Eq. (2). Again, model setup is carried out using data at Askole station (Table 1) during 2005-2008, and lapse rate as from Eq. (1) used to carry out altitude correction. Downscaling of temperature is also carried out using data at Askole station. We used in practice a monthly averaged DT approach and vertical lapse rate as deduced before to project temperature at each belt.

\subsection{Hydrological projections}

We feed CCSM3 downscaled climate projections to the calibrated hydrological model. We consider the decade 20502059 for comparison against our control period (henceforth CO) of 13 yr 1985-1997. To project forward hydrology of the area, one needs some assumptions about ice coverage (Akhtar et al., 2008), and full area/volume budget of glaciers requires indeed more detailed data. In the hypothesis that ice coverage may not increase in the future, we test four scenarios (CCS1-4), namely (i) unchanged glaciers' cover during 2050-2059, CCS1, (ii) - $10 \%$ ice cover during 2050-2059, CCS2, (iii) $-25 \%$ ice cover during 2050-2059, CCS3, and iv) $-50 \%$ ice cover during 2050-2059, CCS4. To do so we reduce glaciers' area moving from the lowest glacierized altitudes towards the highest one, until the proper reduction is obtained.

We then calculate a number of flow indicators. First, we calculate Flow Duration Curves, hereon FDCs (Smakhtin, 2001). FDCs provide visual assessment of the duration of periods (number of days) with discharge above given values, of interest for water resources management as well as for evaluation of ecological effect of flows (Clausen and Biggs, 2000; Dankers and Feyen, 2008). Also we draw some flow descriptors taken by the FDCs (Smakthin, 2001), namely the values of flow discharges equaled or exceeded for a given number of days, $d$, i.e. $Q_{\mathrm{d}}$. We consider $Q_{37}$, or flow exceeded for $10 \%$ of the time, $Q_{91}, 25 \%$ of the time, also known as ordinary flood, $Q_{182}$, i.e. median flow, and $Q_{274}$, also known as ordinary low flow. Also, we evaluate some flow frequency descriptors given by the yearly minima and

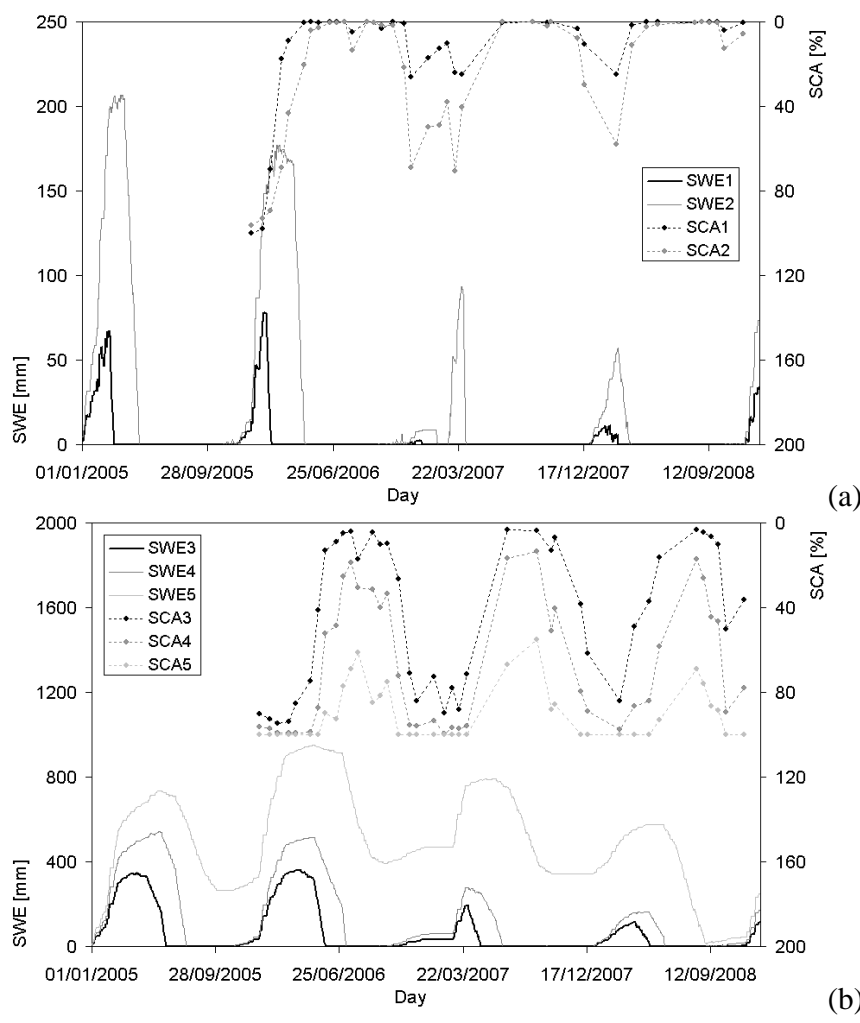

Fig. 4. Modeled Snow Water Equivalent, SWE during 2005-2008 vs. Snow Covered Area, SCA from MODIS. (a) Altitude belts 1-2. (b) Altitude belts 3-5.

maxima of average flows for a given duration $d$, i.e. $Q_{\text {Maxd }}$ and $Q_{\text {Mind }}$. Analysis of these variables is used to pursue statistical appraisal of low flows, e.g. for hydrological drought hazard analysis (Smakhtin, 2001). In Table 5 we report the average of the yearly values of $Q_{\text {Maxd }}$ and $Q_{\text {Mind }}$, for $d=37$, 91,182 , and 274 days. These values provide the spread between the greatest and least flows expected within the Shigar river for increasingly longer periods.

\section{Results}

\subsection{Snow cover}

Figure 4 reports snow cover as simulated by the model during 2005-2008. One constant (in time) value of $D_{\text {Ds }}$ would not provide accurate adaptation, so we adopted monthly variable values of $D_{\text {Ds }}$.

We considered altitude belts 1 to 5 (i.e. until $5375 \mathrm{~m}$ a.s.1.), where most of the snow cover variation occurs (whereas at higher altitudes permanent full snow cover was in practice labeled by both MODIS images and the model). Coupled analysis of SCA and monthly in stream flows during 20062008 (see Fig. 6) suggested use of $D_{\mathrm{Ds}}$ starting from $D_{\mathrm{Ds}}=$ $1.5 \mathrm{~mm}^{\circ} \mathrm{C}^{-1}$ day $^{-1}$ in April (start of the snowmelt season 


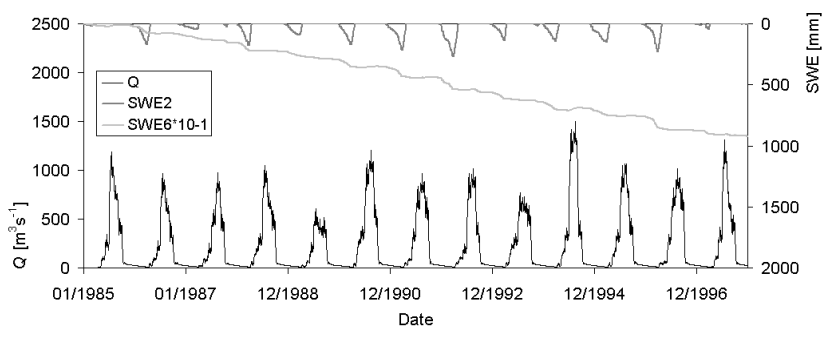

Fig. 5. Shigar at Shigar bridge. Mean daily discharges $Q$ during 1985-1997. Snow water Equivalent SWE in altitude belt 2 and altitude belt 6 (scaled as SWE $\times 10^{-1}$ for readability) reported.

a the lowest altitudes), and approximately linearly increasing by the month until $D_{\mathrm{Ds}}=5 \mathrm{~mm}^{\circ} \mathrm{C}^{-1}$ day $^{-1}$ in August, and then decreasing again until $D_{\mathrm{Ds}}=1.5 \mathrm{~mm}^{\circ} \mathrm{C}^{-1}$ day $^{-1}$ in October. Overall, an average value was obtained of $D_{\mathrm{Ds}}=$ $2.5 \mathrm{~mm}^{\circ} \mathrm{C}^{-1}$ day $^{-1}$.

Notice that MODIS SCA in Fig. 4 refers to maximum value during 8 days, so daily comparison is approximate. Our comparative analysis indicates a visible correspondence between snowpack SWE as simulated by the model and SCA, indicating synchronous patterns (either increase or decrease). Albeit an indication of non null SCA cannot be translated directly into an estimated value of SWE on the ground, one can guess that decreasing SWE within a given altitude belts implies decreased SCA, and the vice versa for increasing SWE. Therefore, a synchronous pattern as reported indicates proper model functioning. Further on, when SCA moves towards low values (i.e. close to zero) the modeled SWE in the corresponding belt tends to zero as well. A sensitivity analysis indicated that for constant (during the snowmelt season) values of $D_{\text {Ds }}$ inaccurate depiction of snow depletion is attained, i.e. snow cover disappears either too late or too soon (or does not disappear at all). Also, coupled analysis of the hydrological budget (monthly discharges in Fig. 6) indicated that use of $D_{\mathrm{Ds}}$ as reported implies an amount of snowmelt from the catchment consistent with the average expected in stream flows, whereas different values of $D_{\text {Ds }}$ would provide either too high or too low discharges at melt.

\subsection{Model performance}

In Table 3 the calibration parameters and performance indicators of the hydrological model are reported. The yearly average discharge simulated from the model is $Q_{\mathrm{av}, \mathrm{m}}=201.70 \mathrm{~m}^{3} \mathrm{~s}^{-1}$ against the observed value of $Q_{\mathrm{av}, \mathrm{o}}=203.73 \mathrm{~m}^{3} \mathrm{~s}^{-1}$ (Bias $=-0.98 \%$ ), while we obtained $\mathrm{MSE} \%=15 \%$. In Fig. 5 we report the daily discharge simulated from our model during 1985-1997, together with snowpack SWE [mm] within two altitude belts (namely belt 2, ca. $3200 \mathrm{~m}$ a.s.l., and belt 6, $5375 \mathrm{~m}$ a.s.1.-6010 $\mathrm{m}$ a.s.l.). Belt 6 represents the first belt where increasing SWE is clearly detected during 1985-1997. One may wonder whether ac-

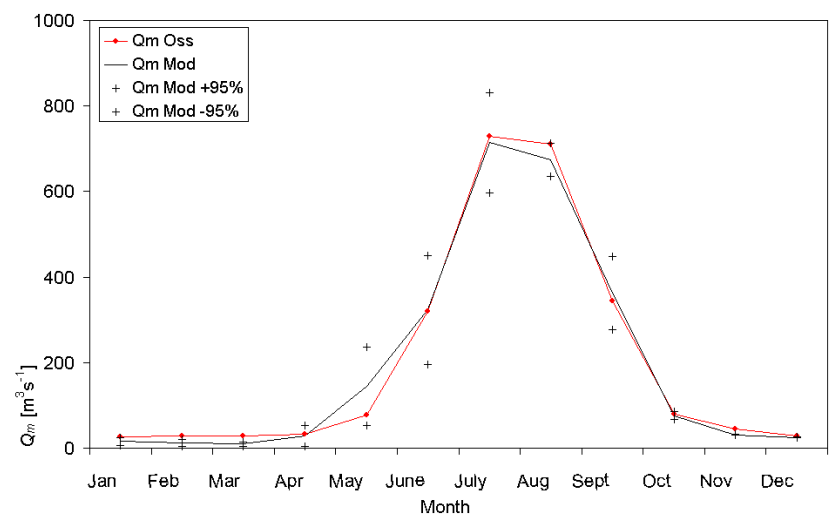

Fig. 6. Shigar at Shigar bridge. Modeled and observed mean monthly discharge $Q_{\mathrm{m}}(1985-1997)$.

cumulation of snow cover at this altitude may be an artifact resulting from the choice to extrapolate a power law describing the increase of precipitation, as depicted here by Eq. (1), above $5000 \mathrm{~m}$ a.s.l. From the available literature, the accumulation area of Baltoro glacier, above which snow cover is expected to accumulate in time (and be transformed into ice), is placed approximately between $4800 \mathrm{~m}$ a.s.l. and $5200 \mathrm{~m}$ a.s.l. (Mayer et al., 2006; Mihalcea et al., 2008). Notice that in Belt 5 (4740-5374 ma.s.1.), covering quite well the expected accumulation region as reported, a variable snow dynamics is seen, with seasonal snow cover in practice (Fig. 4). The circumstance that belt 6 displays snow accumulation would indicate that the model is reasonably able to depict the transition between ablation and accumulation areas. Thus, accumulation in belt 6 seems not an artefact of having too much precipitation, but rather a temperature controlled phenomena, consistent with present knowledge. Also, our MODIS SCA images display permanent snow cover in (and above) belt 6 . The amount of precipitation estimated by Eq. (1) may still be too high, but this seems not to hamper the capacity of our model to describe spatially (i.e. with altitude) ablation and accumulation phenomena.

In Fig. 6, we report modeled monthly mean values during 1985-1997 (plus confidence limits, 95\%), compared against the observed counterparts (Archer, 2003). Confidence limits of the monthly mean as calculated by the model indicate some criticalities of the model. While discharges are quite well represented during the peak months, some inaccuracy in estimation is observed during the raising limb of the monthly hydrograph (slight overestimation in May). Also, low base flows during Spring are slightly underestimated by the model.

Notice that besides obvious presence of inaccuracy of the model, daily disaggregation of weather data may introduce some inaccuracy for daily hydrological cycle simulation. However, such inaccuracy is filtered out at the monthly scale. Further, we tried to minimize percentage error $\mathrm{MSE}_{\%}$, 


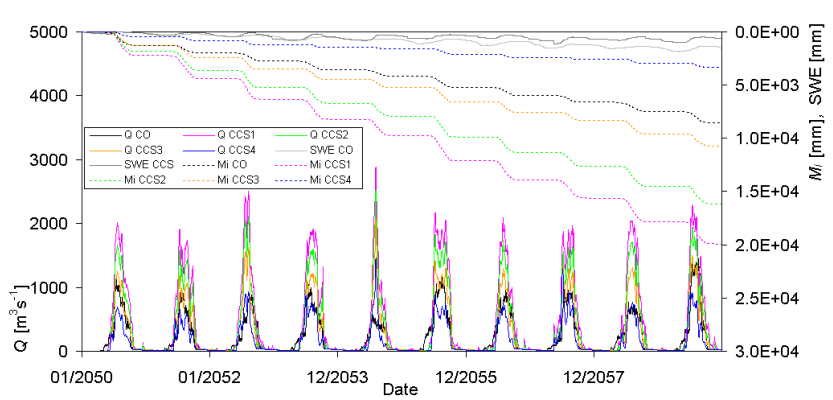

Fig. 7. Shigar at Shigar bridge. Projected discharge $Q$, basin averaged Snow water Equivalent SWE and cumulated ice melt $M_{i}$ during 2050-2059, vs. control series, simulation 1985-1997 (ten years from 1985 to 1994 used for visual comparison).

thus giving equivalent weight to discharge in every month. In fact, one may consider absolute errors, so giving more importance to months with higher discharges. We did not endeavor into a more complicated tuning exercise, say using variable (i.e. with season, or with altitude) values of the hydrological model parameters $\left(S_{\mathrm{Max}}, K, k\right.$, etc.) instead of bulk ones, especially due to lack of related data. Our exercise of hydrologically modeling the Shigar river is not devoted to the exact estimation of in stream discharge (e.g. for forecast, or flood frequency assessment). Rather, we want to preliminarily assess the water resources into this poorly gauged watershed, catching water from a highly glacierized and climate sensitive area, and to investigate potential changes under future climate warming, and the fallout upon local population. In this sense, the minimal model we set up here seems reasonably accurate for the purpose.

\subsection{Future hydrological cycle}

Figures 7 and 8 display the future (2050-2059) discharges within the Shigar river and the related flow duration curves FDCs, compared against control period CO. Also, in Table 4 some relevant weather and hydrological variables are reported for the four investigated glaciers' scenarios. Table 5 contains the statistical flow indicators.

The CCSM3 model predicts for 2050-2059 an increase of temperature of $+1.9^{\circ} \mathrm{C}$ on average, with respect to the control period 2000-2009. CCSM3 also provides increased precipitation, $+20 \%$ or so. Given these weather scenarios, the projected hydrological pattern depends strongly upon the glacier coverage scenarios here proposed. When considering unchanged glacier coverage (CCS1 scenario, with same glacier coverage as presently), discharges at Shigar bridge in Fig. 7 are increased in practice during the whole ablation season, and the yearly average is also increased consistently $\left(442 \mathrm{~m}^{3} \mathrm{~s}^{-1}\right.$, vs. $201.7 \mathrm{~m}^{3} \mathrm{~s}^{-1}$ during 1985-1997). Average snow cover upon the catchment is $\mathrm{SWE}_{\mathrm{av}}=469 \mathrm{~mm}$, against $\mathrm{SWE}_{\mathrm{av}}=1040 \mathrm{~mm}$ during the control period CO (Table 4).

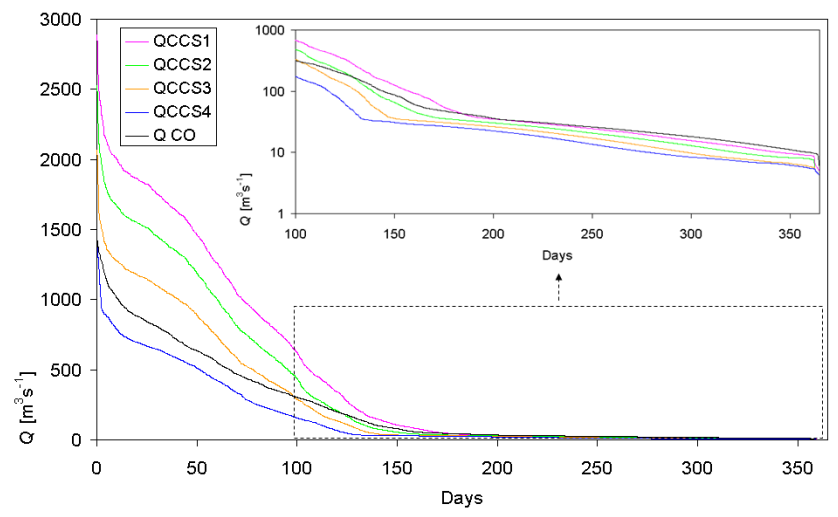

Fig. 8. Projected Flow Duration Curves FDCs during 2050-2059, vs. control series, simulation 1985-1997. Log- $Q$ chart is reported in the zoom to improve readability of low flow discharges.

Average ice melt increases to $\mathrm{ICE}_{\mathrm{av}}=1990 \mathrm{~mm}_{\mathrm{year}}{ }^{-1} \mathrm{vs}$. $\mathrm{ICE}_{\mathrm{av}}=868 \mathrm{~mm}$ year $^{-1}$ from CO scenario, as a consequence of increased temperature at altitudes with noticeable glacier cover area. A side effect of increased precipitation and melting is given by average soil moisture $S_{\mathrm{av}}$ slightly increasing under CCS1 scenario (67 mm vs. $63 \mathrm{~mm}$, see Table 5), thus reaching more often saturation, and aiding in fast overland flow formation, according to Eq. (5).

When a decreasing glaciers' coverage is considered, ice melt tends to decrease with respect to the CCS1 scenario (for CCS2, $\mathrm{ICE}_{\mathrm{av}}=1616 \mathrm{~mm} \mathrm{year}^{-1}$, for $\mathrm{ICE}_{\mathrm{av}}=\mathrm{CCS} 3$, $1070 \mathrm{~mm} \mathrm{year}^{-1}$, for CCS4, ICE $\mathrm{av}=330 \mathrm{~mm} \mathrm{year}^{-1}$, with $-10 \%,-25 \%$, and $-50 \%$ glacier cover respectively). In fact, the lack of glacier cover at the lowest altitudes, where the temperature increase would be more effective for ablation, results into a decrease of ice melt. As a consequence, average discharge decreases with respect to scenario CCS1 (see Tables 4 and 5), and for CCS4 scenario it drops below its control value (scenario $\mathrm{CO}$ ).

Analysis of the FDCs in Fig. 8 displays for scenarios CCS1, CCS2, and CCS3 a more variable flow regime with respect to the control period $\mathrm{CO}$. In fact, higher discharges are seen during thaw season, while similar (CCS1) or lower (CCS2 and CCS3) discharges than for CO are seen during dry season, the latter due to higher temperatures, drawing more moisture under evapotranspiration. Table 5 shows that flows occurring over short duration $(d<182$ days) increase for scenarios CCS1, CCS2, and CCS3, but instead flows over longer duration decrease. A similar behavior is seen when considering frequency flow descriptors, $Q_{\text {Maxd }}$ and $Q_{\text {Mind }} . Q_{\text {Maxd }}$ is generally greater for CCS1, CCS2, and CCS3 than for CO. Instead, $Q_{\text {Mind }}$ is generally lower, except for $d=274$, and more evidently for the shorter durations. Concerning scenario CCS4, all the indicators are below their $\mathrm{CO}$ values, so displaying generalized flow decrease for considerable glacier down wasting. 
Table 4. Most relevant hydrological features (average yearly values). CO is control run. CCS1-4 are CCSM3 scenarios from 1 to 4 . Control run 1985-1997 and scenarios, 2050-2059. Symbol = indicates a value taken as equal to value at its left. In Italic values taken from GCMs and observations, normal font outputs from the hydrological model. Values in mm, weighted average upon altitude belts.

\begin{tabular}{|c|c|c|c|c|c|c|c|}
\hline \multirow{2}{*}{$\begin{array}{l}\text { Variable } \\
P_{\text {CUM }}\left[\mathrm{mm} \mathrm{year}^{-1}\right] \text {, Askole }\end{array}$} & \multirow{2}{*}{$\begin{array}{l}\text { Description } \\
\text { Precipitation }\end{array}$} & \multirow{2}{*}{$\begin{array}{l}\text { Control/Scenario } \\
\mathrm{CO} / \mathrm{CCS} 1 / \mathrm{CCS} 2 / \mathrm{CCS} 3 / \mathrm{CCS} 4\end{array}$} & \multicolumn{5}{|c|}{ Values } \\
\hline & & & 207 & & 25 & & \\
\hline$T_{\mathrm{av}}\left[{ }^{\circ} \mathrm{C}\right]$, Askole & Temperature $3000 \mathrm{~m}$ a.s.1. & $\mathrm{CO} / \mathrm{CCS} 1 / \mathrm{CCS} 2 / \mathrm{CCS} 3 / \mathrm{CCS} 4$ & 5.47 & & 7.. & & \\
\hline$Q_{\mathrm{av}}\left[\mathrm{m}^{3} \mathrm{~s}^{-1}\right]$ & Mean discharge & $\mathrm{CO} / \mathrm{CCS} 1 / \mathrm{CCS} 2 / \mathrm{CCS} 3 / \mathrm{CCS} 4$ & 202 & 442 & 348 & 258 & 154 \\
\hline$S_{\mathrm{av}}[\mathrm{mm}]$ & Mean Soil storage & $\mathrm{CO} / \mathrm{CCS} 1 / \mathrm{CCS} 2 / \mathrm{CCS} 3 / \mathrm{CCS} 4$ & 63 & 67 & 50 & 39 & 35 \\
\hline $\mathrm{SWE}_{\mathrm{av}}[\mathrm{mm}]$ & Mean SWE & $\mathrm{CO} / \mathrm{CCS} 1 / \mathrm{CCS} 2 / \mathrm{CCS} 3 / \mathrm{CCS} 4$ & 1040 & & 46 & & \\
\hline $\mathrm{ICE}_{\mathrm{av}}\left[\mathrm{mmyear}^{-1}\right]$ & Mean ice melt & $\mathrm{CO} / \mathrm{CCS} 1 / \mathrm{CCS} 2 / \mathrm{CCS} 3 / \mathrm{CCS} 4$ & 868 & 1990 & 1616 & 1070 & 330 \\
\hline
\end{tabular}

\section{Discussion}

The proposed exercise of future flow projection provide some interesting insight into the main dynamics of snow and glaciers behavior. Glaciers' covered area in our catchment is laid for approximately $78 \%$ within altitude belts 3 and 5 (i.e. between $3470 \mathrm{~m}$ a.s.l. and $5375 \mathrm{~m}$ a.s.1.), and for approximately $65 \%$ within belt 4 and 5 (i.e. between $4105 \mathrm{~m}$ a.s.l. and $5375 \mathrm{~m}$ a.s.l.).

A key feature of future glaciers' down wasting as projected here is the dynamics of snow cover within these two belts. Figure 9 illustrates simulated SWE and accumulated ice melt $M_{i}$ within these two belts during control period and during 2050-2059. Clearly, during control period, noticeable, albeit not fully permanent snow cover within belt 5 provides shield to the underlying ice, thus limiting considerable ice melt to belt 4 . However, under the future scenario with unchanged glacier cover (CCS1), snow cover in belt five is clearly seasonal, and ice ablation starts at snow thaw. Thus, onset of ablation within belt 5 , containing $33 \%$ of total glacier area, provides a tremendous increase of discharge from ice melt. When glaciers shrinkage is considered (here case CCS4 is shown, $-50 \%$ glacier cover) ice cover decreases, especially in belt 4 , which contains another $33 \%$ of ice cover now (belt $4,-28 \%$ for CCS3, and $-100 \%$, or disappearance, for CCS4, belt $5-3.7 \%$ for CCS4), so that weighted $M_{i}$ drops as well. This in turn decreases in stream flows.

Within altitude belt 6 (5375 ma.s.l. $6010 \mathrm{ma}$ a.s.l.) we found continuous snow cover (not shown for shortness) and thus no ice melt also for the CCS scenarios, indicating that above this altitude no noticeable down wasting should occur within 2059, and the ice melt contributing areas should in practice be limited below $5500 \mathrm{~m}$ a.s.l. or so.

From what is reported here, the hypothesis of a $50 \%$ shrinkage of glaciers' area is not fully unlikely, as lack of permanent snow cover (and thus of glacier recharge) under ongoing climate warming may occur within an area including ca. $80 \%$ of the ice bodies. Initially, ice ablation would provide increased discharges. Besides the obvious positive asset of increased water availability, however, increased in

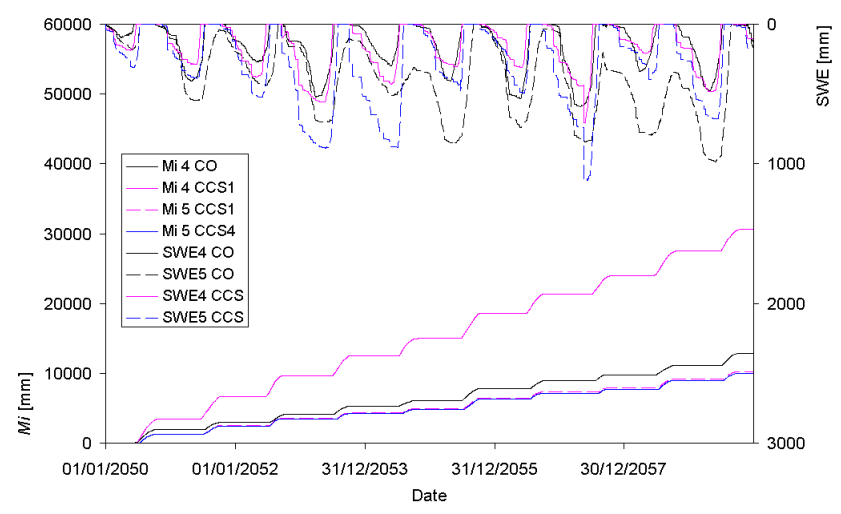

Fig. 9. Projected Snow Water Equivalent SWE and cumulated ice melt $M_{i}$ for altitude belts 4 and 5 during 2050-2059, vs. control series, simulation 1985-1997 (ten years from 1985 to 1994 used for visual comparison).

stream flows and peak floods may fallout into hampered water management. As soon as glacier down wasting triggers, decreased ice ablation will affect flow discharges. Our sensitivity analysis to ice cover scenarios would indicate that an ice cover shrinkage between $25 \%$ and $50 \%$, i.e. disappearance of ice cover between $3500 \mathrm{~m}$ a.s.l. and $4500 \mathrm{~m}$ a.s.l. may be critical already, with considerably decreased water resources, and worsening drought spells.

Our model, explicitly developed for poorly gauged basins, suffers from some possible lacks of accuracy. The proposed melt factor approach is considerably simple in view of the complex dynamics of snow and ice melts, including debris cover. Energy based models are nowadays available for snow and ice melt (Lehning et al., 2002; Nicholson and Benn, 2006; Brock et al., 2007; Rulli et al., 2009), but they may require more information, including sub-daily solar radiation, wind velocity and air moisture, not available here.

Degree day approach for snow melt, calibrated here vs. SCA images, is simple and computationally fast enough to tolerate long term simulation, while reasonably capturing the observed pattern of snow and ice melt and water fluxes. The 
Table 5. Relevant flow variables. CO is control run. CCS1-4 are CCSM3 scenarios from 1 to 4 . Control run 1985-1997 and scenarios, 2050-2059.

\begin{tabular}{|c|c|c|c|c|c|c|c|}
\hline Variable & Description & Control/Scenario & & & Values & & \\
\hline$Q_{37}\left[\mathrm{~m}^{3} \mathrm{~s}^{-1}\right]$ & Exc. $10 \%$ & $\mathrm{CO} / \mathrm{CCS} 1 / \mathrm{CCS} 2 / \mathrm{CCS} 3 / \mathrm{CCS} 4$ & 748 & 1662 & 1370 & 1035 & 603 \\
\hline$Q_{91}\left[\mathrm{~m}^{3} \mathrm{~s}^{-1}\right]$ & Exc. $25 \%$ (ordinary flood) & $\mathrm{CO} / \mathrm{CCS} 1 / \mathrm{CCS} 2 / \mathrm{CCS} 3 / \mathrm{CCS} 4$ & 346 & 758 & 556 & 383 & 200 \\
\hline$Q_{182}\left[\mathrm{~m}^{3} \mathrm{~s}^{-1}\right]$ & Exc. $50 \%$ (median) & $\mathrm{CO} / \mathrm{CCS} 1 / \mathrm{CCS} 2 / \mathrm{CCS} 3 / \mathrm{CCS} 4$ & 42 & 40 & 33 & 28 & 25 \\
\hline$Q_{274}\left[\mathrm{~m}^{3} \mathrm{~s}^{-1}\right]$ & Exc. $66 \%$ (ordinary low) & $\mathrm{CO} / \mathrm{CCS} 1 / \mathrm{CCS} 2 / \mathrm{CCS} 3 / \mathrm{CCS} 4$ & 21 & 18 & 15 & 11 & 10 \\
\hline$Q_{\mathrm{Max} 37}\left[\mathrm{~m}^{3} \mathrm{~s}^{-1}\right]$ & Max av. flow 37 days & $\mathrm{CO} / \mathrm{CCS} 1 / \mathrm{CCS} 2 / \mathrm{CCS} 3 / \mathrm{CCS} 4$ & 855 & 1870 & 1555 & 1181 & 701 \\
\hline$Q_{\operatorname{Max} 91}\left[\mathrm{~m}^{3} \mathrm{~s}^{-1}\right]$ & Max av. flow 91 days & $\mathrm{CO} / \mathrm{CCS} 1 / \mathrm{CCS} 2 / \mathrm{CCS} 3 / \mathrm{CCS} 4$ & 680 & 1477 & 1202 & 899 & 528 \\
\hline$Q_{\operatorname{Max} 182}\left[\mathrm{~m}^{3} \mathrm{~s}^{-1}\right]$ & Max av. flow 182 days & $\mathrm{CO} / \mathrm{CCS} 1 / \mathrm{CCS} 2 / \mathrm{CCS} 3 / \mathrm{CCS} 4$ & 414 & 873 & 689 & 510 & 300 \\
\hline$Q_{\operatorname{Max} 274}\left[\mathrm{~m}^{3} \mathrm{~s}^{-1}\right]$ & Max av. flow 274 days & $\mathrm{CO} / \mathrm{CCS} 1 / \mathrm{CCS} 2 / \mathrm{CCS} 3 / \mathrm{CCS} 4$ & 284 & 587 & 464 & 343 & 203 \\
\hline$Q_{\operatorname{Min} 37}\left[\mathrm{~m}^{3} \mathrm{~s}^{-1}\right]$ & Min av. flow 37 days & $\mathrm{CO} / \mathrm{CCS} 1 / \mathrm{CCS} 2 / \mathrm{CCS} 3 / \mathrm{CCS} 4$ & 11 & 10 & 9 & 6 & 6 \\
\hline$Q_{\operatorname{Min} 91}\left[\mathrm{~m}^{3} \mathrm{~s}^{-1}\right]$ & Min av. flow 91 days & $\mathrm{CO} / \mathrm{CCS} 1 / \mathrm{CCS} 2 / \mathrm{CCS} 3 / \mathrm{CCS} 4$ & 14 & 13 & 10 & 8 & 7 \\
\hline$Q_{\operatorname{Min} 182}\left[\mathrm{~m}^{3} \mathrm{~s}^{-1}\right]$ & Min av. flow 182 days & $\mathrm{CO} / \mathrm{CCS} 1 / \mathrm{CCS} 2 / \mathrm{CCS} 3 / \mathrm{CCS} 4$ & 70 & 98 & 68 & 52 & 47 \\
\hline$Q_{\operatorname{Min} 274}\left[\mathrm{~m}^{3} \mathrm{~s}^{-1}\right]$ & Min av. flow 274 days & $\mathrm{CO} / \mathrm{CCS} 1 / \mathrm{CCS} 2 / \mathrm{CCS} 3 / \mathrm{CCS} 4$ & 274 & 552 & 441 & 329 & 196 \\
\hline
\end{tabular}

use of a variable snow melt factor $D_{\text {Ds }}$ during the thaw seasons seems reasonable, as due to changing snow conditions, while degree day for ice $D_{\mathrm{Di}}$ is normally more stable (Singh et al., 2000).

The model here presented, albeit minimal, requires some amount of data. First, topographic data are necessary, including ice cover mapping. Then, climate data are required, including local observations of air temperature and precipitation (rainfall + snowfall), or at least some extrapolation to high altitudes. Here, for hydrological model calibration, we had to rely upon disaggregation of monthly data, which may introduce further noise at the daily scale.

One should carry out (at least) one comprehensive survey of snow depth distribution upon the glaciers at the onset of snow depletion, in order to link this information to the data from the lower measured stations in the basin, if available, or to initialize SWE in the model (Bocchiola et al., 2010). Indeed, under the umbrella of the SHARE-Paprika project, we plan to carry out at least one such survey within the expected accumulation area of the Baltoro glacier (above $5500 \mathrm{~m}$ a.s.l. or so), which should aid in (i) setting up initial SWE conditions for long term snow melt simulations, and (ii) evaluating properly melt factor $D_{\text {Ds }}$. However, here use of remotely sensed images, widely spread and easily available nowadays, is shown to provide considerable gain in term of snow melt modeling.

The use of extrapolated (via lapse rate) rather than measured temperatures and precipitation (the latter considerably uncertain) may affect the performance of the model, especially during the onset (May, June) and end (September) of the melt season, seen as critical periods here.

A most compelling issue is the assessment of soil retention, here quantified according to the SCS-CN method. In poorly gauged watersheds as here, where soil cover information may lack, bad estimation of soil abstraction may indeed mislead flood prediction, especially in the lowest, possibly vegetated, areas. Because soil use changes may interact with climate to modify flow occurrence in the near future, understanding of soil response is warranted. Therefore, specific focus should be directed on estimation of soil conditions, e.g. using remote sensing devices together with well targeted local investigation.

The projected hydrological scenarios are clearly sensitive to the climate inputs (temperature, precipitation), and with different projected climate inputs (i.e. different $G C M s$ ) different hydrological scenarios would be obtained. Within the present literature some works are available concerning recent and prospective climate and hydrology trends within Karakoram region. Archer and Fowler (2004), and Fowler and Archer (2005) investigated Trends of temperature and precipitation during 1961-2000 for some stations in Northern Pakistan, close to our catchments here. They found spatially varying results, but they highlighted a general increase of Winter temperature (roughly $+0.6{ }^{\circ} \mathrm{C}$ in the considered period), and a cooling in summer (roughly $-1^{\circ} \mathrm{C}$ ), together with an increase in precipitaton during Winter, Summer, and yearly (roughly $+30 \%$ on average). Hewitt (2005), highlighted evidence of glacier expansion in the central Karakoram in the late 1990s, occurring almost exclusively in glacier basins from the highest parts of the range. Possible explanations for this involve increases in precipitation in valley climate stations during the last four decades or so, and small declines in summer temperatures, which may indicate positive trends in glacier mass balance. Here, our reference CCSM3 model provides during Summer (JAS) an increase of $+2.3^{\circ} \mathrm{C}$ on average in the area (2000-2009 vs. 2050-2059), as an increase in precipitation in the order of $+21 \%$ or so during Winter (JFM).

Akhtar et al. (2008) used SRES A2 scenario (20712100) by the PRECIS Regional Climate Model and HBV 
hydrological model to simulate future discharge in three catchments in the $\mathrm{HKH}$, and found increased discharge for $100 \%$ and $50 \%$ glacier scenarios, and predicted in stead a drastic decrease in the $0 \%$ scenario. Their change in temperature (from 1961-2000) is of $+4.5-4.8^{\circ} \mathrm{C}$ yearly $(+4.7-$ $4.8^{\circ} \mathrm{C}$ in Winter, $+4.2-4.8^{\circ} \mathrm{C}$ Summer), against our $+1.9^{\circ} \mathrm{C}$ yearly $\left(+1.8^{\circ} \mathrm{C}\right.$ Winter, $+2.3^{\circ} \mathrm{C}$ in Summer, 2050-2059 vs. 2000-2009), which projected to 2100 would be roughly $+3.9^{\circ} \mathrm{C}$ yearly $\left(1961-2000\right.$ vs. $2071-2100,+4.8^{\circ} \mathrm{C}$ in Summer, $+3.7^{\circ} \mathrm{C}$ in Winter), consistent in practice. Year round precipitation in their area is projected to increase up to $21 \%$, also consistent with our results here (albeit we refer to 2050-2059).

Their results concerning increasing discharge for $50 \%$ glacier cover do indicate different results with respect to our findings here. However, this may be due either to their higher temperature, providing more melting upon a smaller area, or to a different way of calculation of glacier cover.

Notice here that, albeit we used SCA from MODIS for ice melt validation, our hydrological model does not require use of SCA for hydrological simulation (like SRM model, Rango, 1992; Immerzeel et al., 2010), as it implicitly accounts for snow cover budget (and depletion). The same applies in principle to ice cover. This means that, in case an initial condition concerning ice cover area and ice thickness (i.e. volume) would be available within each altitude belt (and neglecting or modeling in some way ice flow down slope), ice budget could be explicitly tracked within the catchment. Therefore, future work may be devoted to estimating in some way ice volume, in order to assess full mass budget for the area (Kuhn, 2003), and climate change effects therein.

The approach we proposed here seems simple enough that portability to catchments nearby should be reasonably practicable. With the caveats underlined above, temperature and precipitation and may be drawn from the low altitude network (and satellite data for reference, as we did with TRMM here). Melt factors for snow may be evaluated based upon (at least) one field campaign, or taken from others studies like ours, and perhaps validated with aid of satellite data for SCA. Analysis of geology and land cover maps should aid in estimating soil retention, especially for the lowest areas. Sensitivity of the hydrological cycle to climate change as projected may be tested in the future using other general/regional climate models plus downscaling based upon the available ground stations as here. A measure of confidence of the projected hydrological cycle (i.e. the spread of the future daily predicted discharges) may also be investigated, say by ensemble simulations based upon the deterministic scenario from the GCMs, which may provide information about day to day variability, while maintaining average statistics substantially consistent with those from the deterministic scenario (Groppelli et al., 2011c). In the future, these options may also be explored. Under the umbrella of the SHARE-Paprika project, we had access to weather and glaciological data only focusing upon the considered area, so it was not possible to test our model in other areas of Karakoram nearby. However, we can suggest use of our approach, in case properly tailored, for those scientists having such data at hand.

\section{Conclusions}

We investigated future ablation flows from a poorly gauged glacierized watershed within $\mathrm{HKH}$ mountain, studied here for the first time in our knowledge. We gathered information from inhomogeneous available meteorological and hydrological data, we used data from former field campaigns to evaluate ice ablation, and we then coupled glaciological concepts to hydrological modeling theory, to obtain a reasonable synthesis of the hydrological patterns from this glacierized area. We used remotely sensed SCA coupled with in stream flows analysis to tune a degree day approach within an area lacking of snow cover data, with interesting results.

We then projected hydrological cycle fifty years ahead from now, and we highlighted the possible consequences of a warming and wetting climate, as expected according to the present literature, upon water resources down slope. The present study clearly cannot depict future conditions with high accuracy (i.e. by providing estimation of future discharges that are "close" to those actually occurring). However, it may give the order of magnitude of the expected hydrological cycle fifty years from now under reasonable hypothesis concerning the evolution of climate and of the glacier coverage.

The present paper provides a relevant and possibly valuable contribution to the ongoing discussion concerning water resources prediction and their future projections in ungauged and poorly gauged basins, and specifically to the PUB decade initiative of IAHS. The proposed approach profits of sparse data from several sources, and is simple enough that portability to other catchments nearby should be reasonably feasible, as required for regional investigation of this high altitude, inaccessible, and yet tremendously important area. Because ungauged watersheds, and particularly high altitude glacierized ones within $\mathrm{HKH}$, are the third pole of the world, storing a tremendous amount or water to be delivered to populations downstream, their duly investigation here forward seems utmost warranted, to aid taking actions for adaptation to climate change effects.

Acknowledgements. The present work was carried out in fulfillment of the SHARE-Paprika project, funded by the EVK2CNR committee of Italy, aiming at evaluating the impact of climate change upon hydrology of the upper Indus river. We hereby acknowledge EVK2CNR committee for providing also weather data from their stations, and PMD for providing monthly data of their stations. We kindly acknowledge Dr. Bodo Bookhagen at UCSB for allowing us use of his TRMM maps of cumulated precipitation upon Himalaya. Three anonymous reviewers are acknowledged for providing useful suggestions to improve the 
paper content and readability. Oxana Savoskul, at the Institute of Geography, Russian Academy of Sciences, is kindly acknowledged for noticing us about the wrong estimation of glaciers' surface in the Shigar catchment we reported in a first version of our paper.

Edited by: A. Castellarin

\section{References}

Ageta, Y. and Kadota, T.: Predictions of changes of glacier mass balance in the Nepal Himalaya and Tibetan Plateau: A case study of air temperature increase for three glaciers, Ann. Glaciol., 16, 89-94, 1992.

Aggarwal, P. K., Joshi, P. K., Ingram, J. S. I., and Gupta, R. K.: Adapting food systems of the Indo-Gangetic plains to global environmental change: key information needs to improve policy formulation, Environ. Sci. Policy, 7, 487-498, 2004.

Aizen, V. B. and Aizen, E. M.: Regime and mass-energy exchange of subtropical latitude glaciers under monsoon climatic conditions: Gongga Shan, Sichuan, China, Journal of Mountain Research and Development, 14, 101-118, 1994.

Aizen, V. B., Aizen, E. M., and Nikitin, S. A.: Glacier regime on the northern slope of the Himalaya (Xixibangma glaciers), Quater. Int., 97-98, 27-39, 2002.

Akhtar, M., Ahmad, N., and Booij, M. J.: The impact of climate change on the water resources of Hindukush-KarakoramHimalaya region under different glacier coverage scenario, J. Hydrol., 355, 148-163, 2008.

Archer, D. R. and Fowler, H. J.: Spatial and temporal variations in precipitation in the Upper Indus Basin, global teleconnections and hydrological implications, Hydrol. Earth Syst. Sci., 8, 4761, doi:10.5194/hess-8-47-2004, 2004.

Archer, D. R.: Contrasting hydrological regimes in the upper Indus Basin, J. Hydrol., 274, 198-210, 2003.

ASTER, Adv. Spaceborn Thermal Emission and Reflection Radiometer, AST14DEM-Rel., http://asterweb.jpl.nasa.gov/ content/03_data/01_Data_Products/release_DEM_relative.htm, 2006.

Bárdossy, A.: Calibration of hydrological model parameters for ungauged catchments, Hydrol. Earth Syst. Sci., 11, 703-710, doi:10.5194/hess-11-703-2007, 2007.

Bavay, M., Lehning, M, Jonas, T., and Löwe, H.: Simulations of future snow cover and discharge in Alpine headwater catchments, Hydrol. Process., 23, 95-108, 2009.

Beniston, M.: Climatic Change and its Impacts. An Overview Focusing on Switzerland, Kluwer Academic Publishers, Dordrecht/The Netherlands and Boston/USA, 2004.

Bhutta, N. M. Smedema, L. K.: One hundred years of waterlogging and salinity control in the Indus valley, Pakistan: a historical review, Irrig. and Drain., 56, S81-S90, 2007.

Bocchiola, D., De Michele, C., and Rosso, R.: Review of recent advances in index flood estimation, Hydrol. Earth Syst. Sci., 7, 283-296, doi:10.5194/hess-7-283-2003, 2003.

Bocchiola, D., De Michele, C., Pecora, S., and Rosso, R.: Sul tempo di risposta dei bacini idrografici italiani [Response time of Italian catchments], L'ACQUA, 1, 45-55, 2004 (In Italian with abstract in English).

Bocchiola, D. and Rosso, R.: The distribution of daily Snow Water Equivalent in the Central Italian Alps, Adv. Water Resour., 30,
135-147, 2007.

Bocchiola, D. and Rosso, R.: Use of a derived distribution approach for extreme floods design: a case study in Italy, Adv. Water Resour., 32, 8, 1284-1296, 2009.

Bocchiola, D.: Regional estimation of Snow Water Equivalent using Kriging: a preliminary study within the Italian Alps, Geografia Fisica e Dinamica Quaternaria, 33, 3-14, http://www. glaciologia.it/gfdq/?p=1742, 2010.

Bocchiola, D. and Groppelli, B.: Spatial estimation of Snow Water Equivalent at different dates within the Adamello Park of Italy, Cold regions science and technology, 63(3), 97-109, 2010.

Bocchiola, D., Mihalcea, C., Diolaiuti, G., Mosconi, B., Smiraglia, C., and Rosso, R.: Flow prediction in high altitude ungauged catchments: a case study in the Italian Alps (Pantano Basin, Adamello Group), Adv. Water Resources, 33(10), 1224-1234, 2010.

Bookhagen, B. and Burbank, D. W.: Topography, relief, and TRMM-derived rainfall variations along the Himalaya, Geophys. Res. Lett., 33, L08405, doi:10.1029/2006GL026037, 2006.

Bookhagen, B. and Burbank, D. W.: Towards a complete Himalayan hydrologic budget: The spatiotemporal distribution of snow melt and rainfall and their impact on river discharge, J. Geophys. Res., 115(F3), 1-25, doi:10.1029/2009jf001426, 2010.

Brock, B. W., Rivera, A., Casassa, G., Bown, F., and Acuña, C.: The surface energy balance of an active ice-covered volcano: Volcán Villarrica, southern Chile, Ann. Glaciol., 45, 104-114, 2007.

Brutsaert, W.: Hydrology: an introduction, Cambridge University Press, 2005.

Burn, D. H.: Catchment similarity for regional flood frequency analysis using seasonality measures, J. Hydrol., 202, 212-230, 1997.

Buytaert, W., Reusser, D., Krause, S., and Renaud, J. P.: Why can't we do better than Topmodel?, Hydrol. Process., 22, 4175-4179, 2008.

Cagnati, A., Crepaz, A., Macelloni, G., Pampaloni, P., Ranzi, R., Tedesco, M., Tomirotti, M., and Valt, M.: Study of the snow melt-freeze cycle using multi-sensor data and snow modelling, J. of Glaciol., 50(170), 419-426, 2004.

Campbell, J. G.: Inventory of Glaciers, Glacial Lakes and the Identification of Potential Glacial Lake Outburst Floods (GLOFs) Affected by Global Warming in the Mountains of India, Pakistan and China/Tibet Autonomous Region, Final report for APN project 2004-03-CMY-Campbell. Kathmandu, Nepal: International Centre for Integrated Mountain Development; Kobe, Japan: Asia-Pacific Network for Global Change Research, 2004.

Castellarin, A., Burn, D. H., and Brath, A.: Assessing the effectiveness of hydrological similarity measures for flood frequency analysis, J. Hydrol., 241, 270-285, 2001.

Castellarin A., Burn, D. H., and Brath, A.: Homogeneity testing: how homogeneous do heterogeneous cross-correlated regions seem?, J. Hydrol., 360, 67-76, 2008.

Castiglioni, S., Lombardi, L., Toth, E., Castellarin, A., and Montanari, A.: Calibration of rainfall-runoff models in ungauged basins: A regional maximum likelihood approach, Adv. Wat. Resour., 33, 1235-1242, 2010.

Ceres, F., Chirico, G. B., and Romano, N.: Considerazioni sulla stima della capacità idrica di campo in suoli uniformi e stratificati [Assessment of water content within uniform and stratified soils], Proceedings: IX Convegno Nazionale dell'Associazione 
Italiana di Ingegneria Agraria, Ischia Porto, 12-16 Settembre 2009, Memoria 3-44, 2009.

Chalise, S. R., Kansakar, S. R., Rees, G., Croker, K., and Zaidman, M.: Management of water resources and low flow estimation for the Himalayan basins of Nepal, J. of Hydrol., 282, 25-35, 2003.

Chen, J. M., Chen, X., Ju, W., and Geng, X.: Distributed hydrological model for mapping evapotranspiration using remote sensing inputs, J. of Hydrol., 305, 15-39, 2005.

Clausen, B. and Biggs, B. J. F.: Flow variables for ecological studies in temperate streams: groupings based on covariance, J. Hydrol., 237, 184-197, 2000.

Dankers, R. and Feyen, L.: Climate change impact on flood hazard in Europe: An assessment based on high resolution climate simulations, J. Geophys. Res., 113, D19105, doi:10.1029/2007JD009719, 2008.

Foppa, N., Wunderle, S., Hauser, A., Oesch, D., and Kuchen, F.: Operational sub-pixel snow mapping over the Alps with NOAAAVHRR data, Ann. Glaciol., 38, 245-252, 2004.

Fowler, H. J. and Archer, D. R.: Hydro-climatological variability in the Upper Indus Basin and implications for water resources, Proceedings: Symposium S6 held during the Seventh IAHS Scientific Assembly at Foz do Iguaçu, Brazil, April 2005), IAHS Publ., 295, 131-138, 2005.

Gabriele, S. and Arnell, N.: A hierarchic approach to regional flood frequency analysis, Wat. Resour. Res., 27(6), 1281-1289, 1991.

Georgievsky, M. V.: Application of the Snowmelt Runoff model in the Kuban river basin using MODIS satellite images, Environ, Res, Lett,, 4(4), 045017, doi:10.1088/1748-9326/4/4/045017, 2009.

Groppelli, B., Bocchiola, D., and Rosso, R.L Precipitation downscaling using random cascades: a case study in Italy, Adv. Geosci., 8, 1-6, 2010.

Groppelli, B., Bocchiola, D., and Rosso, R.: Spatial downscaling of precipitation from GCMs for climate change projections using random cascades: a case study in Italy, Water Resour. Res., 47, W03519, doi:10.1029/2010WR009437, 2011a.

Groppelli, B., Soncini, A., Bocchiola, D., and Rosso, R.: Scenari futuri di risorsa idrica nei bacini Alpini: Il caso del fiume Oglio [Future water resources scenario within Alpine catchments: the case study of Oglio river], L'ACQUA, 1, 9-24, 2011 b (Italian, with abstract in English).

Groppelli, B., Soncini, A., Bocchiola, D., and Rosso, R.: Evaluation of future hydrological cycle under climate change scenarios in a mesoscale Alpine watershed of Italy, Nat. Haz. Earth Sys. Scie., 11, 1769-1785, 2011c.

Hall, D. K., Riggs, G. A., Salomonson, V. V., DiGiromamo, N., and Bayr, K. J.: MODIS Snow- Cover Products, Remote Sens. Environ., 83, 181-194, 2002.

Hall, D. K., Riggs G. A., and Salomonson, V. V.: MODIS Snow Products, User Guide for Collection Data Products., 2003a.

Hall, D. K., Riggs, G. A., and Salomonson, V. V.: MODIS /Terra Snow Cover 5-min L2, Swath 500 m, December 2003, National Snow and Ice Data Centre, 2003b.

Hall, D. K., Riggs, G. A., Foster, J. L., and Kumar, S. V.: Development and evaluation of a cloud-gap-filled MODIS daily snowcover product. Remote Sens. Environ., 114(3), 496-503, 2010.

Hannah, D. M., Kansakar, S. L., Gerrard, A. J., and Rees, G.: Flow regimes of Himalayan rivers of Nepal: nature and spatial patterns, J. Hydrol., 308, 18-32, 2005.
Hauser, A., Oesch, D., Foppa, N., and Wunderle, S.: NOAA AVHRR derived aerosol optical depth over land, J. Geophys. Res., 110, D08204, doi:10.1029/2004JD005439, 2005.

Hewitt, K.: The Karakoram Anomaly? Glacier expansion and the "elevation effect", 'Karakoram Himalaya, Mountain Research and Development, 25(4), 332-340, 2005.

Hock, R.: Temperature index melt modelling in mountain areas, J. Hydrol., 282, 104-115, 2003.

Immerzeel, W. W., Droogers, P., de Jong, S. M., and Bierkens, M. F. P.: Large-scale monitoring of snow cover and runoff simulation in Himalayan river basins using remote sensing, Remote Sens. Environ., 113, 40-49, 2009.

Immerzeel, W. W., van Beek, L. P. H., and Bierkens, M. F. P.: Climate Change Will Affect the Asian Water Towers, Science, 328, 1382-1385, 2010.

IPCC, Intergovernmental Panel for Climate Change: Climate change 2007: The scientific basis. Cambridge: Cambridge University Press, 2007.

Kahlown, M. A., Raoof, A., Zubair, M., and Kemper, W. D.: Water use efficiency and economic feasibility of growing rice and wheat with sprinkler irrigation in the Indus Basin of Pakistan, Agric. Wat. Manag., 8(7), 292-298, 2007.

Kaser, G., Großhauser, M., and Marzeion, B.: Contribution potential of glaciers to water availibility in different climate regimes, Proceedings of the National Academy of Sciences, 107, 2022320227, 2010.

Kehrwald, N. M., Thompson, L. G., Tandong, Y., MosleyThompson, E., Schotterer, U., Alfimov, V., Beer, J., Eikenberg, J., and Davis, M. E.: Mass loss on Himalayan glacier endangers water resources, Geophys. Res. Lett., 35, L22503, doi:10.1029/2008GL035556, 2008.

Konz, M., Uhlenbrook, S., Braun, L., Shrestha, A., and Demuth, S.: Implementation of a process-based catchment model in a poorly gauged, highly glacierized Himalayan headwater, Hydrol. Earth Syst. Sci., 11, 1323-1339, doi:10.5194/hess-11-13232007, 2007.

Kuhn, M.: Redistribution of snow and glacier mass balance from a hydro meteorological model. J. Hydrol., 282, 95-103, 2003.

Lehning, M., Bartelt , P., Brown, B., and Fierz, C.: A physical SNOWPACK model for the Swiss avalanche warning Part III: meteorological forcing, thin layer formation and evaluation, Cold Regions Science and Technology, 35, 169-184, 2002.

Mayer, C., Lambrecht, A., Belò, M., Smiraglia, C., Diolaiuti, G.: Glaciological characteristics of the ablation zone of Baltoro Glacier, Karakoram, Ann. Glaciol., 43, 123-131, 2006.

Mayer, C., Lambrecht, A., Mihalcea, C., Belò, M., Diolaiuti, G., Smiraglia, C., and Bashir, F.: Analysis of Glacial Meltwater in Bagrot Valley, Karakoram Based on Short-term Ablation and Debris Cover Observations on Hinarche Glacier, Mountain Research and Development, 30(2), 169-177, 2010.

Merz, R. and Blöschl, G.: A regional analysis of event runoff coefficients with respect to climate and catchment characteristics in Austria, Water Resour. Res., 45, W01405, doi:10.1029/2008WR007163, 2009.

Mihalcea, C., Mayer, C., Diolaiuti, G., Lambrecht, A., Smiraglia, C., Tartari, G.: Ice ablation and meteorological conditions on the debris covered area of Baltoro Glacier (Karakoram, Pakistan), Ann. Glaciol., 43, 292-300, 2006.

Mihalcea, C., Mayer, C., Diolaiuti, G., D'agata, C., Smiraglia, C., 
Lambrecht, A., Vuillermoz, E., and Tartari, G.: Spatial distribution of debris thickness and melting from remote-sensing and meteorological data, at debris-covered Baltoro glacier, Karakoram, Pakistan, Ann. Glaciol., 48, 49-57, 2008.

Ming, J., Cachier, H., Xiao, C., Qin, D., Kang, S., Hou, S., and $\mathrm{Xu}, \mathrm{J}$.: Black carbon record based on a shallow Himalayan ice core and its climatic implications, Atmos. Chem. Phys., 8, 13431352, doi:10.5194/acp-8-1343-2008, 2008.

Nakicenovic, N. and Swart, R. E.: IPCC, 2000 - Emissions Scenarios. Cambridge University Press, UK, 570 pp., 2000.

Nicholson, L. and Benn, D.: Calculating ice melt beneath a debris layer using meteorological data, J. Glaciol., 52, 178, 463-470, 2006.

Over, T. M. and Gupta, V. K.: Statistical analysis of mesoscale rainfall: dependence of a random cascade generator on large scale forcing. J. Appl Meteorol., 33, 1526-1542, 1994.

Parajka, J., Merz, R., and Blöschl, G.: A comparison of regionalisation methods for catchment model parameters, Hydrol. Earth Syst. Sci., 9, 157-171, doi:10.5194/hess-9-157-2005, 2005.

Parajka, J. and Blöschl, G.: The value of MODIS snow cover data in validating and calibrating conceptual hydrologic models, J. Hydrol., 358, 240-258, 2008.

Peel, M. C., Finlayson, B. L., and McMahon, T. A.: Updated world map of the Kppen-Geiger climate classification, Hydrol. Earth Syst. Sci., 11, 1633-1644, doi:10.5194/hess-11-16332007, 2007.

Rango, A.: Worldwide testing of the snowmelt runoff model with applications for predicting the effects of climate change, Nord. Hydrol., 23, 155-172, 1992.

Rosso, R.: Nash model relation to Horton order ratios, Wat. Resour. Res., 20(7), 914-920, 1984.

Rulli, M.C., Mihalcea, C., Diolaiuti, G., and Bocchiola, D.: A distributed hydrological model for an Italian debris covered glacier, IAHS Publications, Proceedings: $8^{\text {th }}$ Scientific Assembly, Hyderabad. Manuscript Available upon request, 2009.

Sarwar, A. and Perry, C.: Increasing water productivity through deficit irrigation: evidence from the Indus plains of Pakistan, Irrig. and Drain., 51, 87-92, 2002.

Seibert, J. and Beven, K. J.: Gauging the ungauged basin: how many discharge measurements are needed?, Hydrol. Earth Syst. Sci., 13, 883-892, doi:10.5194/hess-13-883-2009, 2009.

Simaityte, J., Bocchiola, D., Augutis, J., and Rosso, R.: Use of a snowmelt model for weekly flood forecast for a major reservoir in Lithuania, Ann. Glaciol., 49, 33-37, 2008.

Simpson, J. J., Stitt, J. R., and Sienko, M.: Improved estimates of the areal extent of snow cover from AVHRR data, J. Hydrol., 204, 1-23, 1998.
Singh, P., Kumar, N., and Arora, M.: Degree-day factors for snow and ice for Dokriani Glacier, Garhwal Himalayas, J. Hydrol., 235, 1-11, 2000.

Sivapalan, M. and 13 co-authors: IAHS decade on Predictions in Ungauged Basins (PUB), 2003-2012: Shaping an exciting future for the hydrological sciences, Hydrol. Sci. J., 48(6), 857-880, 2003.

Smakhtin, V. U.: Low flow hydrology: a review, J. Hydrol., 240, 147-186, 2001.

Smiraglia, C., Mayer, C., Mihalcea, C., Diolaiuti, G., Belò, M., and Vassena, G.: Ongoing variations of Himalayan and Karakoram glaciers as witnesses of global changes: Recent studies of selected glaciers, Developments in Earth Surface Processes, 10, 235-248, 2007.

Soil Conservation Service: Urban Hydrology for small watersheds, U.S. Department of Agriculture, Washington D.C., 1975, updated, 1986.

Soncini, A. and Bocchiola, D.: Assessment of future snowfall regimes within the Italian Alps using general circulation models, Cold Reg. Sci. and Technol., in press, COLTEC 1651, doi:10.1016/j.coldregions.2011.06.011, 2011.

Swamy, A. N. and Brivio, P. A.: Hydrological modeling of snowmelt in the Italian Alps using visible and infrared remote sensing, Int. J. Remote Sensing, 17(16), 3169-3188, 1996.

Timlin, D. J., Ahuja, L. R., Pachepsky, Y., Williams, R. D., Gimenez, D., and Rawls, W.: Use of Brooks-Corey parameters to improve estimates of saturated conductivity from effective porosity, Soil Sci. Soc. Am. J., 63, 1086-1092, 1999.

Wang, L., Koike, T., Yang, K., and Yeh, P. J.: Assessment of a distributed biosphere hydrological model against streamflow and MODIS land surface temperature in the upper Tone River Basin, J. Hydrol., 377, 21-34, 2009.

Weiers, S.: Zur Klimatologie des NW-Karakoram und angrenzender Gebiete. StatistischeAnalysen unter Einbeziehung von Wettersatellitenbildern und eines Geographischen Informationssystems (GIS), Bonner Geographische Abhandlungen, 92, Bonn, Germany: Geographisches Institut, Universitat Bonn, 1995.

Wigmosta, M. S., Vail, L. W., and Lettenmaier, D. P.: A distributed hydrology-vegetation model for complex terrain, Wat. Resour. Res., 30, 1665-1679, 1994.

Winiger, M., Gumpert, M., and Yamout, H.: KarakoramHindukush-western Himalaya: Assessing high-altitude water resources, Hydrol. Process., 19, 2329-2338, 2005.

Xu, B., Cao, J., Hansen, J., Yao, T., Joswia, D. R., Wang, N., Wu, G., Wang, M., Zhao, H., Yang, W., Liu, X., and He, J.: Black soot and the survival of Tibetan glaciers, PNAS, 106, 52, 2211422118, doi:10.1073/pnas.0910444106, 2009. 